\title{
FINANCING INVENTORY THROUGH FIELD WAREHOUSING
}

FIELD warehousing is a financing device. It thus differs from its ancestor, terminal warehousing, which is primarily used for storage and distribution. ${ }^{1}$ The technique of field warehousing may be sketched in broad outline. An independent warehouse company acts as the custodian of inventory against which a businessman, usually a manufacturer, seeks to secure credit. ${ }^{2}$ From the warehouseman's standpoint, the operation is in the "field," although the goods do not leave the borrower's premises. ${ }^{3}$ The items to be "warehoused" are segregated from the rest of the borrower's stock, ${ }^{4}$ in an area leased for a nominal sum to the warehouse company ${ }^{5}$ and demarcated with signs and physical barriers. ${ }^{8}$ The

The Editors of the Jontrnal wish to thank the representatives of various field-imarchouse companies, banks, and finance companies who supplied the information for much of this Comment; undocumented material herein was obtained, and some of the older literature brought up to date, through interviews with them.

1. See Union Trust Co. v. Wilson, 198 U.S. 530, 538 (1905); Heffron v. Bank of America Nat. Trust \& Sav. Ass'n, 113 F2d 239, 242 (9th Cir. 1940) ; Frenesuch, Public Warehouses in Distribution 11 (1955); Jacoby \& Sauldieg, Finaxcing Isiventori ON Fiedd Warehouse Recerpts 13 (1944) [hereinafter cited as Jacobr \& Sallaifa]; Prochnow \& Foulke, Practical Bank Credit $404-06$ (2d ed. 1950); Everberg, Thic Warehouse Receipt-Credit Security and Financing Derices, 54 Cosr. L.J. 51 (1949); Friedman, Field Warchousing, 42 Colux. L. Rev. 991,992 n.8, 1012 (1942).

2. Frenerick, Using Public Warehouses 43 (1957); Fricdman, supra note 1, at 991. See generally Jacoby \& Saulnier; Schnemer, Find Waremousing (1941) (hereinafter cited as Schneider]; SweEtser, Finawcing Goods, 291-402 (1957) [hereinafter cited as SwEetser]; Mastellon, Administration of Field Warehouse Loans, 1958 [hereinafter cited as Mastellon].

Field warehousing has been utilized in a vast number of contexts. See note 178 infra. But its chief customers are manufacturers. See JACOBY \& SAuLNiEn 35-38 (manuiacturers used $66.6 \%$ of the field warehouses operated by 5 leading companies in 1941); Letter From Thomas Clines, Vice Pres., New York Terminal Warchouse Co., to Yalc Lat' Journal, June 16, 1959, on file in Yale Law Library ("half of our business comes irom manufacturers"). See also Letter From Henry D. Bugg, Vice Pres., St. Louis 'Terminal Field Warehouse Co., to Yale Law Journal, July 22, 1959, on file in Yale Law Library; Letter From Harry D. Hamilton, Director of Public Relations, Douglas-Guardian IVarehouse Corp., to Yale Law Journal, June 17, 1959, on file in Yale Law Library; Smith, Security Pledged on Member Bank Loans to Business, 33 Fed. Reserve Buld C64, 671 (1947).

3. See Love v. Export Storage Co., 143 Fed. 1 (6th Cir. 1905); Frederics, Usisc Public Warehouses 43 (1957).

4. See Friedman, supra note 1, at 1000-01; Frederrch, PuBuic Warehouses Is: Distribution 13 (1955).

5. See Friedman, supra note 1, at 996; SweEtSer 292-307 (form of lease), 317-21

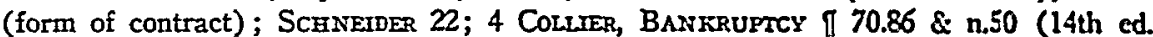
repl. 1959) [hereinafter cited as Collies].

6. The signs are to notify all those dealing with the borrower that goods are not in his control or possession. See New York Law Revision Comm'n, Report and Record of Hearings on the Uniform Commercial Code, N.Y. LEG. Doc. No. 65, vol. 2, at 1192-93 (1954) (statement of J. Francis Ireton) [hereinafter cited as New York Hearings]; 
borrower's usual clerk is employed by the warehouse company to exercise control over the goods on its behalf. ${ }^{7}$ As items of inventory are deposited, warehouse receipts are issued against them. ${ }^{8}$ These documents, which "embody" the goods, ${ }^{9}$ are pledged as collateral for a bank loan, ${ }^{10}$ and released to the borrower as repayment is made, or in exchange for new receipts, or on other agreed terms.11 Thus a lender, through a documentary pledge, can in effect secure a valid lien on a shifting stock of inventory, ${ }^{12}$ often otherwise unattainable. ${ }^{13}$

Legal literature on field warehousing has been largely devoted to determining the mechanics prerequisite to a valid bailment with the warehouseman. But, since field warehousing is a highly developed and concentrated industry, the expertise of the handful of companies which operate ninety-five per cent of field warehouses renders mechanical problems simple and routine. ${ }^{14}$ While the traditional requirements continue to condition the method and cost

4 COLLIER f 70.86 , at $1699-1704 \&$ n. 45 . The physical barriers are to enable the warehouseman to take exclusive control of the goods. See SwEETSER 307-10.

7. See SWEETSER 310-17 (form of employment contract); 4 ColuIER If 70.86, at 1702 \& n.46 (collecting cases); Friedman, supra note 1, at 1002-03; SCHNEIDER 23-24.

8. The field warehouse companies normally issue nonnegotiable warchouse receipts. See Sweetser 325-35 (form of receipts); Mastellon 35-38; Sampsell v. Lawrence Warehouse Co., 167 F.2d 885 (9th Cir. 1948) (form of receipt in issue). But negotiable warchouse receipts may also be issued. Peek, Warehouse Receipt Financing, June 1953, Oct. 1954, pp. 47-49 [hereinafter cited as Peek]; SchneIDER 14-16; see New York Tcrminal Warehouse Co. v. Bullington, 213 F.2d 340 (5th Cir. 1954); notes 211-18 infra and accompanying text.

9. See Gilmore \& Axelrod, Chattel Security: I, 57 Yale L.J. 518,522 \& n.12 (1948).

10. See Friedman, supra note 1, at 991, 1012-13; Birnbaum, Form and Substance in Ficld Warehousing, 13 LAw \& Contenr. Prob. 579-80 (1948).

11. See SweEtser 335-49 (forms); Mastellon 38-44 (forms); Friedman, supra note 1 , at 1004 .

12. Such a security interest is often called a floating lien, one that attaches to the borrower's present and future inventory. See Stone, The "Equitable Mortgagc" in Now" York, 20 CoLun. L. Rev. 519, 531-33 (1920). On floating liens under English and Canadian law and under the Uniform Commercial Code, see Coogan \& Bok, The Impact of Article 9 of the Uniform Commercial Code on the Corporate Indenturc, 69 Y ALE L.J. 203, 251-59 (1959); Coogan, Article 9 of the Uniform Conmercial Code: Prioritics Among Secured Creditors and the "Floating Lien," 72 HARv. L. REv. 838, 839 \& n.2 (1959).

13. See Gilmore \& Axelrod, supra note 8, at 533-40; Birnbaum, Articlc 9 of thi Uniform Commercial Code-Secured Transactions, 6 Q. Rep. Conference on Personal Finance Law 4, 5 (1951); Cohen \& Gerber, Mortgages of Merchandise, 39 Colum. L. REv. 1338 (1939) (difficulties of obtaining a floating lien).

Section 9-204 of the Uniform Commercial Code directly validates the floating lien. UNIFORM COMMERCIAL CODE $\$ 9-204$ \& comment [hereinafter cited as UCC and refering to the 1958 official draft unless otherwise stated]. See Statements of Milton J. Kupfer in 2 New York Hearings 1147-55, 1164, 1202-04 (questioning both the wisdom of the floating lien and whether $\S 9-108$ of the Code will validate the floating lien against section 60 (a) of the Bankruptcy Act), answered in part by Coogan, supra note 12, at 854.

14. See Sweetser 370-71, 397-98; Letter From Donald K. Miller, American Express Field Warehousing Corp. to the New York Law Revision Commission, Sept. 17, 1954, in 1 New York Hearings 728, 735-36. 
of operation, ${ }^{15}$ the issues of greatest current interest and importance concern the economics of the field-warehousing industry; the incidence of loss from the borrower's default or dishonesty; the emerging practice of financing distribution by manufacturers' shipments of products to field warehouses on dealers' premises; and the impact of the Uniform Commercial Code. Indeed, it has been suggested that field warehousing would become outmoded upon adoption of Code provisions validating direct agreements conveying a security interest in a shifting body of inventory. ${ }^{10}$ This idea follows naturally from preoccupation with the means by which field warehousing validates a lender's lien vis-avis third parties, ${ }^{17}$ but attaches insufficient importance to the lender's innate interest in protecting the collateral from dissipation by the borrower. ${ }^{18}$ A full assessment of field warehousing must therefore comprehend its collateralpolicing as well as its lien-validating functions, and view them in comparison with competing devices in the secured credit market.

This Comment accordingly will undertake a reappraisal of field warehousing. First will come a comparison, both legal and functional, with other nonCommercial Code methods of inventory finance. Then the traditional material on the legal requirements of a valid field warehousing arrangement will be reviewed, followed by a description of the mechanics employed to meet such requirements. Third, the Comment will examine the economics of the fieldwarehousing industry. The incidence of loss problem will then be considered in an analysis of priorities among lenders and of several recent cases on allocation of the loss resulting from missing goods between lender, borrower, and warehouseman. Next treated is field warehousing's most recent offshoot, the financing of distribution through secured trade credit. Finally, the Comment will evaluate its topic in light of the Uniform Commercial Code.

\section{Field Warehousing in Context: Alternative Methods of Inventory Finance}

Field warehousing is but one device considered by a bank furnishing shortterm working capital and seeking security therefor. For such a bank, ideal

15. See Miller, Seven Steps in the Protection of Loans Based on IVarchouse Reccipts, Bankers Monthly, Dec 1949, p. 7.

16. See Everett, Securing Security, 16 Law \& Contearp. Prob. 49, 56 (1951) (written when Code required filing to perfect field warehousing security interest); Stidham, Secured Laans Under the Uniform Commercial Code (Article IX), 75 Baskasc L.J. 475, 477-78 (1958). But cf. Robinson, Commercial Lendsisg Under the Uniform Commercial Code, 73 Banking L.J. 77, 80 (1956). Gilmore, Chattel Security: II, 57 YALE L.J. 761, 777 (1948), suggests that field warehousing might never have come into existence if a floating lien had always been available.

17. See Everett, suprä note 16, at 56; cf. Hownold, Cases on Sales axd Sales Financing 486-87 (1954).

18. See Kripke, Article 9: Secured Transactions Under the Uniform Commercial Code in Penusylvania, 15 U. PITt. L. Rev. 602, 606-07 (1954); Birnbaum, Article 9-A Restatement and Revision of Chattel Security, 1952 WIs. L. REv. 349, 365-66; Robinson, supra note 16, at 80; Mass. Bankers Ass's, Bankers MAanual on the Uxiform ComMercial CODE 149 (1958); cf. Gilmore, supra note 16, at 541 \& n.62. 
collateral would be self-liquidating, easily administered, difficult to dissipate, and legally protected from possible competing claimants. ${ }^{10}$ But the bank's choice is frequently one between inventory and accounts receivable, even though both are difficult to supervise. ${ }^{20}$ Receivables are often simpler to evaluate and easier to realize upon in case of default ${ }^{21}$ banks choose receivables over inventory as collateral in a slight majority of cases. ${ }^{22}$ But to the small- and medium-size business borrower, inventory finance is often crucial, ${ }^{23}$ and, according to Federal Reserve System figures for 1955, accounted for 9.2 per cent of all business secured loans, 10.9 per cent of secured loans made to manufacturers and miners, and 32.9 per cent of secured loans made to wholesalers. ${ }^{24}$

When inventory is selected, four methods of encumbrancing are feasible: trust receipts, factors' liens, and pledges of terminal or field warelıouse re-

19. See Jacoby \& Saulnier 61-62; Federal Reserve System, Financing Sulall. Business, Report to the Committee on Banking and Currency and the Select Committee on Small Business, United States Congress 403-11 (Comm. Print, 1958) [hereinafter cited as Financing Sarall Business]; Mass. Bankers Ass'N, op. cit. supra note 18 , at 107-09.

20. But the borrower may have other business or personal assets or may be able to produce some other person willing to guarantee his loan. Those bankers interviewed indicated that each loan application presented specific problems that had to be worked out in light of the needs of the parties, the credit standing of the borrower, and the collateral available for security. See also Smith, Security Pledged on Member Bank Loans to Business, 33 FED. REserve BulL. 664, 665-70 (1947). Banks prefer personal guaranties and pledges of insurance policies or readily marketable securities, if available as collateral. See Cagle, Security Pledged on Business Loans at Member Banks, 45 Fed. Reserve Bull. 1114, 1121 (1959); SweEtser 123-93 (bank loan procedures). The borrower on the other hand would probably prefer to pledge business rather than personal assets.

Plant and equipment financing is usually used for longer term credit at higher interest rates than inventory or receivables financing. The collateral is usually more difficult to sell after a default. See Cagle, supra at 1121-22; JACoBy \& SAULnier 62. See generally SaUlnier \& Jacoby, Financing Equipnent for Commercial and Industrial ENTERPRISE (1944).

Intangibles or contract rights may also be used as security. See Comment, Contract

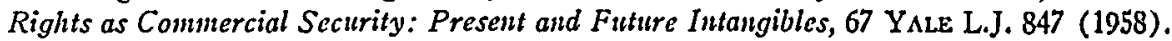

21. See, e.g., Andrews, Friedland \& Shapiro, Working-Capital of Small Busincss, 24 LAw \& Contemp. Prob. 68, 86 (1959); Funk, Secured Borroning by Small Business, 13 Bus. LAw. 335, 338 (1958).

22. See Cagle, supra note 20 , at 1126 . In 1946 , however, banks had almost three times as many inventory loans as receivable loans outstanding. See Smith, supra note 20, at 665. Finance companies have an even greater "preference for receivables over inventory. See Koch, Economic Aspects of Inventory and Receivables Financing, 13 LAw \& ContEMr. Prob. 566, 573-74 (1948); Financing Sisall Business 450-52.

23. See, e.g., Smith, supra note 20, at 664; Mastellon 1-2; Frederick, Usinc Punlic Warenouses 46 (1957); Funk, supra note 21, at 343-45; Kripke, The "Securcd Transactions" Provision of the Uniform Commercial Code, 35 VA. L. REv. 577, $582-83$ (1949); cf. Financing Small Business 384-85.

24. See Cagle, sipra note 20, at 1126. See also Financing Small Business 403-11. 
ceipts. ${ }^{25}$ Trust receipts have not been widely adopted in domestic commerce outside of automobile dealer financing and, more recently, "floor planning" of other consumer durables. ${ }^{20}$ While trust receipts enable the lender-the "entruster"-readily to acquire a valid lien on the goods and their proceeds and are usually preludes to purchase of dealers' highly profitable consumer paper, ${ }^{27}$ they can ordinarily be used only to secure new inventory. ${ }^{28}$ The scope of the factor's lien acts is not thus limited. They allow a lender to obtain a continuing lien on a borrower's present and after-acquired inventory through compliance with statutory requirements for a written agreement and notice filing. ${ }^{29}$ Most of these acts, however, have been hastily and poorly drafted, with the result that lenders are reluctant to rely on factors' liens outside of the few industries in which their use has become traditional, ${ }^{30}$ Both trust receipts and factors' liens have an additional disadvantage; the security interest in the goods is lost if they are sold to bona fide purchasers in the ordinary course of business, ${ }^{31}$ though the lien usually shifts to the proceeds of such a sale as compensation. 32

In contrast to trust receipt and factor's lien arrangements, warehousing places the collateral in the possession of an independent bailee and gives the

25. Chattel mortgages, conditional sales and pledges are poorly suited to inventory financing and are infrequently used. See generally Gilmore \& Axelrod, Chaltel Securify: I, 57 YALE L.J. 517 (1948). Nor are the security interests available under the Uniform Commercial Code considered throughout most of this Comment. See notes 253-326 infro and accompanying text.

26. See Gilmore, stipra note 16, at 764-68 ("first notable use" was oceasioned by growth of automobile industry); Guthasann \& Dougald, Corporate Financial Poucr 433 (3d ed. 1955) [hereinafter cited as Guthasann \& Dougard]. See also Sweetser 499-594 (procedures and forms used in trust receipting).

27. See Gilmore, The Commercial Doctrine of Good Faith Purchase, 63 YALE L.J. 1057,1102 (1954).

28. See UnIforar TruSt Receipts Act $\$ 2$ [hereinafter cited as UTRA]; B-W ACceptance Corp. v. Benjamin T. Crump Co., 199 Va. 312, 99 S.E.2d 606 (1957); Gilmore, Chattel Security: II, 57 YALE L.J. 761, 766-68 (1948); Dunham, Inecutory and Accounts Receivable Financing, 62 HARv. L. REv. 588, 592 (1949).

But some states have amended UTRA $\S 2$ to permit the trust reccipting of goods already in the possession of the trustee. E.g., FLA. Star. AnN. $\$ 673.02$ (Supp. 1958). For other state statutes, see 9C Uniforar Laws Awn. 238-39 (1957).

29. See, e.g., N.Y. Pers. Prop. Law § 45; Onlo Rev. Code Axs. $\S \S 1311.59-.64$ (Page 1953) ; Tex. Crv. Stat. Ann. art. 5505c (1955); Dunham, stipra note 28 , at 592; Mloore \& Kupfer, Factor's Liens and Accounts Receivable-Current Developments, 12 Bus. Law: 482 (1957); Honnold, Cases on Sales and Sales Finanieing 508-10 \& n.t (1954) (listing states). On the history of factors' acts, see Steffen \& Danziger, The Rebirth of the Commercial Factor, 36 Coluar. L. REv. 745 (1936).

30. See, e.g., Gilmore, Chattel Security: II, 57 YALE L.J. 761, 770.71 (1943); Stidham, Secured Loans Under the Uniform Commercial Code (Arlicle IX), 75 Baskisc L.J. 475, 477 (1958); Funk, supra note 21, at 343-44.

31. See UTRA § 9; Orio Rev. Code Ann. \$ 1311.62 (Page 1953); Tex. Civ. Stat. ANN. art. 5506c, \& 4 (1958).

32. See UTRA § 10; N.Y. Pers. Prop. Law § 45; Tex. Civ. Stat. Axs. art. 5506e, § 4 (1958). 
lender a pledgee's interest in receipts (and therefore in the inventory), valid against third-party claimants. The borrower must tolerate loss of possession and the additional cost of placing the merchandise in a warehouse. Of course, he is not pleased with these requirements, and if they prove too burdensome he will forego this means of financing. Yet, just as the lender overcomes the borrower's natural preference for an unsecured rather than a secured loan, he may be in a strong enough bargaining position to demand warehousing. Warehouse receipts have an additional advantage to a bank; they can be rediscounted through the Federal Reserve System. ${ }^{34}$ More important, both federal and state banking laws permit banks to lend in excess of normal legal limits for any one borrower if his loan is secured by warehouse receipts. ${ }^{30}$ Since the legal limit is a specified percentage of a bank's capital, warehousing may be the only method by which a small bank can aid a local business. ${ }^{30}$ In any event, a businessman who borrows against pledged warehouse receipts often obtains a larger loan than he could under any other arrangement, and sometimes at a lower interest rate. ${ }^{37}$ As between terminal and field warehousing, the former is utilized when the borrower is located far from his prospective market and prefers to have his finished product in a public warehouse close to the purchaser. ${ }^{38}$ Field warehousing is likely to be more economical if the borrower has idle space of his own, and is essential if he needs to use the inventory on his premises or if the goods are too bulky to be moved to a terminal warehouse. ${ }^{30}$ Banks often prefer the receipts of the major fieldwarehouse companies to those of terminal warehouses because of the large liability insurance policies they carry, their expertise in policing pledged goods, and their sound financial reputation. ${ }^{40}$ On the whole, however, terminal warehousing, despite its primary role as a means of storage and distribution, is used more frequently than field warehousing for credit purposes. ${ }^{41}$

33. Cf. Financing Smali Business 403-06, 408, 410. See generally Prochnow \& Foulke, Practical Bank Credit 339-423 (2d ed. 1950).

34. See JacoBy \& SaULnIER 63. This privilege is unavailable, however, when the borrower's former stock clerk is the warehouse custodian, as is ordinarily the case.

35. See Schneider 2-4; Friedman, Field Warchousing, 42 CoLun. L. REv. 991,993 (1942) ; Beaty, More States Recognize Field Warehotuse Receipts as Good Collatcral, 56 BANKERS MONTHLY 595 (1939).

36. Cf. Frederick, Using Public Warehouses 46-47 (1957).

37. See Smith, supra note 20; at 672-75; SchNeIDER 32; notes 169, 171-72 iufra. On the other hand, the field-warehouse borrower may be putting up relatively more collateral to obtain the same loan than he would under a receivable loan.

38. See Sweetser 365-66; Frederick, Using Public Warehouses 20-29 (1957).

39. See Sweetser 365-66; FrederICK, Using Public Warehouses 45 (1957).

40. Cf. SwEEtSER 370-71, 390-91. For cases where field warehouses were set up in already existing grain warehouses, see First Nat'1 Bank v. Petzoldt, 262 F.2d 540 (10th Cir. 1958) ; William H. Banks Warehouses, Inc. v. Jean, 96 F. Supp. 731 (D. Idlaho 1951) (abortive attempt to set up field warehouse).

41. See Smith, supra note 20, at 671-73 (table 10). When terminal warehouse receipts are used as security, however, it seems likely that the pledged goods are warehoused pri- 
Because of the adoption in every state of the Uniform Warehouse Receipts Act [UWRA] (or the Commercial Code), ${ }^{42}$ a lender can everywhere obtain a security interest in inventory based on pledged warehouse receipts. With trust-receipts and factor's-lien loans, as well as assignments of accounts receivable, his locale is more restricted, since not all states have protected such transactions by statute. ${ }^{43}$ Warehousing arrangements easily satisfy whatever policing standards the jurisdiction imposes on the lender, ${ }^{44}$ since an independent party supervises the inventory; under the other devices, the bank may itself be required to police the loan to ensure its validity. ${ }^{\text {to }}$ This fact, coupled with the lender's obvious dominion over the representative receipts, may account for the courts' early acceptance of field warehousing ${ }^{40}$ while competing devices were encountering judicial hostility. Finally, a pledgee's remedies upon default are more efficacious than those of an entruster or a factor's-lien lender. Under a pledge agreement, the lender has the right to sell the collateral in his possession "to himself or anyone else, whenever and wherever he wants, at public or private sale, with or without notice, provided only that he promises to pay the surplus, if any, to the pledgor."4t Since the goods are "locked up" in the warehouse receipt, they can be sold simply by transferring or negotiating the document. ${ }^{48}$ Repossession procedure under

marily for storage or distribution reasons and would be there whether credit was desired or not.

42. See 3 Uniform Laws ANN. xxy (1959) (adoption of UWRA). The Uniform Commercial Code became effective in Pennsylvania on July 1, 1954, PA. STAт. Axx. tit. 12A, as amended, $\mathrm{Pa}$. Laws 1959, Act 426, and in Massachusetts on October 1, 1958, Mrass. AnN. Laws ch. 106 (Spec. Supp. 1958), as amended, Mass. Acts 1959, ch. 580. The Code has also been adopted by Kentucky, Ky. Acts 1958, ch. 77, Connecticut, Conn. Pub. Acts 1959, No. 133, and New Hampshire, to be published as N.H. REv. Stax. ANN. ch. 253A, to become effective in these states on July 1, 1960, October 1, 1961, and July 1, 1961, respectively.

43. UTRA has been adopted in 33 states and Puerto Rico. See 9C Uxrrorar Laws Ann. 220 (1957) (listing states); 3 Condit. Sale-Chat. Mont. Rer. If $5301-5455$ (outline of state case law). Factor's lien acts are now found in 28 states in a variety of forms. See Moore \& Kupfer, supra note 29, at 492; Honnold, Cases ox Sales and Sales FinasicING 508-10 (1954). Accounts-receivable statutes appear in 37 states, and also vary widely among themselves. See Comment, 67 Y ALE L.J. 402,409 (1958); Conwill \& Ellis, Much Ado About Nothing: The Real Effect of Amended 60(a) on Accosmis Reccirable Financing, 65 Harv. L. Rev. 62 (1950); Moore \& Kupfer, supra note 29, at 483.

44. See Benedict v. Ratner, 268 U.S. 353 (1925); Lee v. State Bank \& Trust Co., 38 F.2d 45 (2d Cir. 1930); Dunham, supra note 28, at 593; Comment, 67 Yale L.J. 402, 405-06 \& nn.17-22 (1958).

45. See Note, 24 N.Y.U.L.Q. Rev. 598 (1949); Note, 101 U. PA. L. Rav. 392 (1952).

46. See Union Trust Co. v. Wilson, 198 U.S. 530 (1905); Philadelphia Warchouse Co. v. Winchester, 156 Fed. 600 (D. Del. 1907) ; Love v. Export Storage Co., 143 Fed. 1 (6th Cir. 1906).

47. Gilmore, Article 9 of the UCC-Part $V, 7$ Q. Rep. Conference on Pensosal. Finance Law 4, 5 (1952); see Everberg, The Warchouse Reccipt-Credit Sccurity and Financing Derice, 54 Coxr. L.J. 51, 60 (1949).

48. UWRA $\$ 37,39,41,42$. In the case of a nonnegotiable receipt, the transferce must also notify the warehouseman of the transfer. 
the Uniform Trust Receipts Act [UTRA] is somewhat more cumbersome, while most factor's lien acts make no provision for liquidation of the collateral upon default. ${ }^{50}$

In the event of the borrower's bankruptcy, field warehousing is tactically more advantageous to the lender than trust receipt or factor's lien plans. If the trustee in bankruptcy attacks the arrangement, by alleging that the warehouseman lacked control over the goods, the bank can leave the concluct and expense of the suit to the field warehouse company, which will defend its bailment. ${ }^{51}$ When collateral is in the hands of the borrower, as uncler UTRA or the factor's lien acts, the trustee takes possession ${ }^{62}$ and the lender must bring a reclamation proceeding in the bankruptcy court to recover the goods. ${ }^{\text {na }}$ But when a lender possesses the collateral, under a substantial adverse claim of right, the trustee must institute a plenary action to acquire it ${ }^{54}$ a lender's possession of field warehouse receipts gives him such a claim. ${ }^{65}$ Thus, under field warehousing, the lender does not have to take any affirmative action to protect his security, and the bankruptcy trustee will not often take the onus of challenging its validity. ${ }^{50}$

\section{Field Warehousing in Legal Doctrine: Received Learning Concerning the Bailment's Validity}

Although isolated instances of field warehousing appear somewhat earlier, specialization was first inaugurated by William $\mathrm{H}$. Banks Warehouses, Inc., in 1892, as a direct outgrowth of its experience in terminal warehousing for

49. See UTRA § 6.

50. See Gilmore, Chattel Security: II, 57 YaLE L.J. 761, 770 \& n.39 (1948). Those that do are the more recent statutes, such as VT. STAт. ANN. tit. 9, § 1859 (1958); Wis. Stat. Ann. $\$ 241.145(7)$ (1957). These provisions for liquidation are also more cumbersome than default procedures in a field warehouse arrangement.

51. See Funk, supra note 21, at 348; Miller, Seven Steps in the Protection of Loans Based on Warehouse Receipts, Bankers Monthly, Dec. 1949, p. 7; Hoover, Check List for Loans on Field Warehouse Receipts, 29 Buln. Rogerr MoRRIs Assocs. 23, 24 (1946). The warehouseman is usually named by the trustee as defendant and therefore must defend his bailment. Moreover, he does not have to own the deposited goods to be a party to a suit involving their disposition in bankruptcy. See Bradley v. St. Louis Terminal Warehouse Co., 189 F.2d 818 (8th Cir. 1951).

52. Bankruptcy Act, § 70a, 52 Stat. 879 (1938), as amended, 11 U.S.C. $\$ 110$ (1958).

53. See In $r e$ Lake's Laundry, Inc., 79 F.2d 326 (2d Cir. 1935); In re White Plains Ice Service, Inc., 109 F.2d 913 (2d Cir. 1940).

54. See Harrison v. Chamberlain, 271 U.S. 191 (1926); Rockmore v. New Jerscy Fid. \& Plate Glass Ins. Co., 65 F.2d 341 (2d Cir. 1933) ; Livingston \& Kearns, Commercial Financing and the Relation Betzeen Secured and Unsecured Creditors in Bankruptcy, 13 LAW \& CONTEMr. Prob. 609, 616 (1948).

55. Bradley v. St. Louis Terminal Warehouse Co., 189 F.2d 818 (8th Cir. 1951); Moore, Cases on Debtors' and Creditors' Rights 522-23 (1955); 2 Collier II 23.06[3].

56. See note 92 infra.

57. E.g., Union Trust Co. v. Trumbull, 137 I1l. 146, 27 N.E. 24 (1891) ; Yenni v. McNamee, 45 N.Y. 614 (1871). 
security purposes. ${ }^{58}$ Terminal warehouses had long been recognized as choice custodians for goods serving as collateral. ${ }^{58}$ In accordance with traditional pledge principles, ${ }^{60}$ collateral would be forfeited upon default, and the warehouse would deliver the inventory upon presentation of the receipt.01 This method of secured financing was simple and expedient; it did not require filing, as would, for example, a chattel mortgage $;^{02}$ the warehouseman's possession precluded ostensible ownership of and dominion over the goods by the borrower. ${ }^{63}$ When moving the goods to a warehouse was too expensive or too disruptive of the borrower's business, the warehouse was moved to the goods. Field warehousing emerged when the realization that possession of collateral could thus be transferred coincided with a demand for credit sufficient to justify the cost of the operation. Its expansion was greatly facilitated once UWRA, promulgated in 1907, made warehouse receipts, wherever issued, universally acceptable in American commerce. ${ }^{\text {b4 }}$

The early case law on field warehousing accepted the arrangement so long as certain basic requirements were met. ${ }^{\circ 5}$ Union Trust Co. v. Wilson ${ }^{00}$

58. SWEETSER 397 ; JACOBY \& SAULNIER 13.

59. See Peek 1; Sweetser 210; Frederick, Public Waremouses in Distrmutto: 16-17 (1955) ; Merchandise Div., American Warehousemen's Ass'n, Warehouse Receipts as Collateral, 1957 , p. 4.

60. The basic requirement for a valid pledge, in order to defeat lien creditors of the pledgor, is that possession of the collateral be transferred from the pledgor to the pledgee or his agent. E.g., Casey v. Cavaroc, 96 U.S. 467 (1877); Taplinger v. Northwestern Nat'l Bank, $101 \mathrm{~F} .2 \mathrm{~d} 274$ (3d Cir. 1938). Whether the transfer of possession is adequate depends upon the nature and location of the collateral. See In re Wyoming Valley Collieries Co., 29 F. Supp. 106, 109 (M.D. Pa. 1939) (field warehouse pledge); Bush v. Export Storage Co., 136 Fed. 918 (E.D. Tenn. 1904) (same); 4 Colurer II 70.86, at 1701-03. On pledges generally, see Brown, Personal Property $\$ \S 128-36$ (1936).

61. See Gilmore, Article 9 of the Uniform Commercial Code-Part V, 7 Q. REP. Conference on Personal Finance Law 4, 5 (1952) (pledge law favorable to creditor); Note, 66 YALE L.J. 257 (1956) (foreclosure procedure); SweETSER 124-36 (iorms of pledge agreements).

62. See, c.g., Dirigo Tool Co. v. Woodruff, 41 N.J. Eq. 336, 7 Att. 125 (Ct. Err. \& App. 1886).

63. See Dale v. Pattison, 234 U.S. 399 (1914); First Nat'l Bank v. Harkness, 42 W. Va. 156, 24 S.E. 548 (1896); 4 Coltrer If 70.86, at 1696-98; Statement of J. Francis Ireton, in 2 New York Hearings 1193; Comment, 31 Texas I. REv. 167, 193-94 (1952).

64. See Mohun, The Effect of the Uniform Warchouse Receipts Act, 13 Coluss. L. Rev. 202 (1913) ; Honnold, Cases on Sales and Sales Financing 318 (1954); Burman, Practical Aspects of Inventory and Reccizables Financing, 13 LAW \& Cositarr. Proв. 555, 562-63 (1948); Koch, Economic Aspects of Inzentory and Recrizables Finaneing, 13 id. at 566, 570; Mastellon 4-5. One of the main reasons for the passage of UWRA was facilitation of the use of warehouse receipts as collateral. Sce Braucher, The Uniform Commercial Code-Documents of Title, 102 U. PA. L. REv. 831, 857 (1954); Pcok 13. No evidence has been found to indicate that field-warehouse interests played a part in the drafting and promulgation of UWRA. They may, however, have assisted in obtaining its passage in the state legislatures. Cf. note 271 infra.

65. See Philadelphia Warehouse Co. v. Winchester, 156 Fed. 600 (D. Del. 1907); Love v. Export Storage Co., 143 Fed. 1 (6th Cir. 1906).

66. 198 U.S. 530 (1905). 
established that a good faith transfer of inventory to an independent warehouse conducted on the borrower's premises was a sufficient change in possession to justify issuance of valid warehouse receipts and therefore was not in derogation of the rights of competing creditors. The warehouse receipts retained their usual efficacy even though the motive of the bailment was admittedly the acquisition of pledgeable documents, not storage. ${ }^{67}$ The bailee's economic independence was often said to be essential for the pledge to be valid. ${ }^{68}$ When the bailor sought to save expenses by setting up his own warehouse corporation, it was likely to be held invalid on the theory that bailment with a "subsidiary warehouse" could not effect a genuine change of control, or issue receipts valid under UWRA. ${ }^{60}$ And even were the courts to uphold arrangements in which the borrower's employee or subsidiary is the warehouseman, ${ }^{70}$ banks would probably not be willing to forego the advantage of an independent guardian of their interests.

More troublesome than the requirement of the bailee's independence were those of his "open, exclusive, and unequivocal possession."71 Notoriety was held sufficient when warehouse signs would adequately inform inspecting creditors that the inventory was encumbered. ${ }^{72}$ Exclusiveness of possession necessitated locking the inventory within the leased area, set off by barriers such as the classic chicken-wire fence. ${ }^{73}$ Unequivocal possession by the ware-

67. See 198 U.S. at 538; Heffron v. Bank of America Nat. Trust \& Sav. Ass'n, 113 F.2d 239 (9th Cir. 1940); Simpson \& Doeller Co. v. Sears \& Nichols Corp., 25 F. Supp. 200, 202 (S.D. Ohio 1938).

68. See, e.g., Union Trust Co. v. Trumbull, 137 Ill. 146, 23 N.E. 355 (1898) ; National Bank of Commerce v. Flanagan Mills \& Elevator Co., 268 Mo. 547, 188 S.W. 117 (1916); 4 COLLIER \I 70.86.

69. See Honnold, Cases on Sales and Sales Financing $485-86$ (1954); cases cited note 68 supra.

70. See American Can Co. v. Erie Preserving Co., 183 Fed. 96 (2d Cir. 1910) ; Dunn v. Train, 125 Fed. 221 (1st Cir. 1903) ; Muhleman \& Kayhoe, Inc. v. Brown, 43 Del. (4 Terry) 207, 45 A.2d 521 (1945) (borrower's employee supervision held adequate policing apparently because goods were extremely cumbersome). A borrower-sponsored warehouse was upheld as against a competing consignor in Lippincott Distrib. Co. v. Peoples Commercial \& Sav. Bank, 137 Ohio St. 399, 30 N.E.2d 691 (1940).

71. Security Warehousing Co. v. Hand, 143 Fed. 32, 41 (7th Cir. 1906), aff'd, 206 U.S. 415 (1907); see In re Spanish-American Cork Prod. Co., 2 F.2d 203 (4th Cir. 1924) ; MacGaffey Canning Co. v. Bank of America, 109 Cal. App. 415, 294 Pac. 45 (Dist. Ct. App. 1930); Friedman, Field Warehousing, 42 Colum. L. REv. 991, 996-1002 (1942).

72. Compare Heffron v. Bank of America Nat. Trust \& Sav. Ass'n, 113 F.2d 239 (9th Cir. 1940) (signs contributed to adequate notice), and Equitable Trust Co. v. A. C. White Lumber Co., 41 F.2d 60 (D. Idaho 1930) (same) with In re Spanish-American Cork Prod. Co., 2 F.2d 203 (4th Cir. 1924) (notice inadequate because no signs). Sec SWEETSER 308-09.

73. Compare Ribaudo v. Citizens Nat'l Bank, 261 F.2d 929 (5th Cir. 1958) (scparate floor for field warehouse achieves adequate segregation), and Laube v. Scattle Nat'l Bank, 130 Wash. 550, 228 Pac. 594 (1924), with McGaffey Canning Co. v. Bank of America, 109 Cal. App. 415, 294 Pac. 45 (Dist. Ct. App. 1930) (bailment invalid because, inter alia, no physical barriers). See SWEETSER 307-10 (methods of segregation). 
houseman entails exclusion of the borrower from access to the goods without authorization by the bailee. ${ }^{74}$ On the crucial issue raised by the practice of employing the borrower's former stock clerk as the warehouse's custodian, ${ }^{75}$ the courts proved willing to disregard the potentialities of the ex-employer's retaining de facto control so long as its actual exercise was not in evidence. ${ }^{70} \mathrm{On}$ the whole, the case law evolved no mechanical rule for ascertaining whether all three requirements were met. Rather, the decisions turned on an overall assessment of all the facts, and generally upheld the operation in the absence of some flagrant violation of the warehouseman's possession.

In addition to attacks on the details of particular operations, field warehousing in general was subject to the challenge that its operators did not meet UWRA's definition of "warehousemen" as those "lawfully engaged in the business of storing goods for profit."77 Literally, the language is inapposite to the field warehouseman, who is in the business of custodianship, not storage, and who earns his profit for services rendered, not area rented. ${ }^{78}$ Courts have, nevertheless, been willing to extend the act's coverage into the field. In any event, a contrary view would not put the field warehouses out of business, since under the common law the arrangement could be deemed a pledge of inventory to the agent-the "warehouseman"-of the pledgee-the bank- valid as to strangers to the transaction. ${ }^{79}$ The chief advantage of bringing field ware-

74. Security Warehousing Co. v. Hand, 206 U.S. 415 (1907); see Friedman, supra note 71, at 996-1002. But see cases discussed in notes 94-96 infra and accompanying text.

75. See Schnetder 23-24; JacoBy \& SAULNier 26-29; Friedman, supra note 71, at $1002-03$.

76. Compare Love v. Export Storage Co., 143 Fed. 1 (6th Cir. 1906) (former employee approved), with McGaffey Canning Co. v. Bank of America, 109 Cal. App. 415, 294 Pac. 45 (Dist. Ct. App. 1930) (bailment invalid; former employee as custodian is a "significant circumstance"). See SweETSER 310-16. For cases in which the custodian was under the control of his former employer, but no reported attack was made against the bailment, see Lawrence Warehouse Co. v. Twohig, 224 F.2d 493 (8th Cir. 1955) ; Nasif v. Lawrence Warehouse Co., 122 F. Supp. 562 (S.D. Miss. 1954).

Although the courts have accepted this arrangement, the Federal Reserve System and the Administrator of the United States Warehouse Act, 39 Stat. 486 (1916), as amended, 7 U.S.C. $\$ \$ 241-73$ (1958), will not accept receipts issued by a warchouse company employing as custodian the borrower's former employee. See 7 C.F.R. $\$ 151.6$ (1959) (Agriculture Dep't Reg.) ; Friedman, stpra note 71, at 1002-03 (listing opposing arguments); JACOBY \& SAULINIER $27-29$.

77. UWRA § 58(1). (Emphasis added.) See Union Trust Co. v. Wilson, 198 U.S. 530 (1905) ; Love v. Export Storage Co., 143 Fed. 1 (6th Cir. 1906) ; Laube v. Seattle Nat'l Bank, 130 Wash. 550, $228 \mathrm{Pac} 594$ (1924) (all rejecting arguments that the warchouse receipts to be valid must be issued by a warehouseman physically in possession of the goods in his own actual warehouse). While UWRA does not explicitly mention ficld warehousing, a UCC comment classifies it as warehousing so long as the depositor and warchouseman are not the same party. UCC § 1-201, comment 45.

78. But see Frederick, Using Public Warehouses 48 (1957).

79. See Dunn v. Train, 125 Fed. 221 (1st Cir. 1903); In re Cincinnati Iron Store Co., 167 Fed. 486 (6th Cir. 1909) ; American Can Co. v. Erie Preserving Co., 183 Fed. 96 (2d Cir. 1910) ; In re Wyoming Collieries Co., 29 F. Supp. 105, 109 (M.D. Pa. 1939): 4 Colxter If 70.86 , at $1461 \&$ n.61. 
housing within the UWRA definition is the resulting uniformity of detail, without which the companies and their customers would have to contend with the varying and sometimes uncertain common-law standards of fifty state jurisdictions.

A second general attack on field warehousing is made available if bulk sales statutes are construed to cover transfers made by means of documentary pledge. ${ }^{80}$ Such statutes require notice to existing creditors in the event of any "sale ... [or] transfer ... in bulk ... otherwise than in the ordinary course of trade." 81 In most jurisdictions the question is still open whether a pledge is a "sale or transfer" within the meaning of the acts, ${ }^{82}$ although the California and Kansas statutes have been so construed. ${ }^{83}$ Thus, a competing creditor may argue that the field warehouse mechanism is invalid, since no attempt is ever made to comply with the bulk-sales notice provisions. ${ }^{84}$ The few reported decisions on point have rejected such a challenge to the field-warehousing transaction, but usually in such perfunctory manner that it does not appear whether the court believed no pledge could come within the state statute or for some unannounced reason excepted field-warehousing transactions from the consequences attaching to other pledges. ${ }^{85}$ It would be difficult, in the absence of legislative direction, ${ }^{86}$ for a state which otherwise considers bulk pledges as bulk sales to find any policy justification for separate treatment of field warehouses. The Ninth Circuit has ruled that UWRA implicitly repealed any provisions of the California bulk sales act which applied to pledges of warehouse receipts. ${ }^{87}$ But UWRA does not purport to legalize each and every transfer

80. See Ribaudo v. Citizens Nat'1 Bank, 261 F.2d 929 (5th Cir. 1958); Barry v. Lawrence Warehouse Co., 190 F.2d 433 (9th Cir. 1941); Bradley v. St. Louis Terminal Warehouse Co., 189 F.2d 818 (8th Cir. 1951); Heffron v. Bank of America Nat. Trust \& Sav. Ass'n, 113 F.2d 239 (9th Cir. 1940); Friedman, supra note 71, at 1005-08.

81. E.g., N.Y. Pers. Prop. Law \& 44. See generally Honnold, Cases on Sales \& Sales Financing 346-67 (1954); Miller, The Effect of the Bulk Sales Article on Existing Commercial Practices, 16 LAw \& ContENP. ProB. 267 (1951); Billig \& Smith, Bulk Sales Lawe: Transactions Covered by These Statutes, 39 W. VA. L. Rev. 323 (1933).

82. See Friedman, supra note 71, at 1006; Miller, supra note 72, at 272. Most states, however, have held that bona fide chattel mortgages are not within the purview of the statutes. See Wiesner, Florida Bulk Sales Law, 12 Miami L. Rev. 189, 195 (1958); UCC \& 9-111, comment; Nat'L Ass'n of Credit Management, Credit Manual of Comasercial Laws 361 (1959).

83. In re Convisser, 6 F.2d 177 (9th Cir. 1925) (California); C. B. Norton Jewelry Co. v. Maddock, 115 Kan. 108, 222 Pac. 113 (1924).

84. See Billig \& Smith, Bulk Sales Laws: A Study in Statutory Interpretation, 38 W. VA. L. Rev. 309, 319-23 (1932); 4 Colliter If 70.74 \& n.6 (citing cases).

85. See cases cited note 80 supra.

86. See ARK. Stat. Ann. § 68-1504 (1957) (explicitly exempting both public and ficld warehouse pledges); CAL. CIv. CODE ANN. $\$ 3440.5$ (exempting warehouse receipts when "a copy of such receipt is kept at the principal place of business of the warehouseman and at the warehouse in which said goods are stored").

87. Heffron v. Bank of America Nat'l Trust \& Sav. Ass'n, 113 F.2d 239, 242 (9th Cir. 1.940) (under $\$ 42$ of UWRA the receipt holder after notifying the warchouseman had the latter's direct obligation to deliver the goods and this "circumscribes . . . the rights of 
of a warehouse receipt; 88 a transfer violative of a bulk sales act may well remain subject to that act, regardless of UTWRA. ${ }^{80}$ Several states, moreover, adopted their bulk sales act subsequent to UWRA, ${ }^{00}$ so that the converse of the Ninth Circuit's reasoning would find conflicting provisions, if any do exist, in the latter superseded. A satisfactory solution ultimately may be reached through widespread passage of the Uniform Commercial Code, which expressly excludes all perfected security interests from bulk sales regulations. ${ }^{01}$

Field-warehousing cases testing the bailment's validity have almost ceased to appear in the reports. ${ }^{92}$ Several factors account for this. First, field warehousing has become dominated by a few experienced firms whose familiarity with the legal requirements and the methods of satisfying them make noncompliance unlikely. ${ }^{93}$ Second, past decisions in favor of receipt-holders have made trustees in bankruptcy and other creditors' representatives feel that it is not worthwhile to challenge field warehousing arrangements. The only reported attempts in the past five years are not likely to encourage similar ventures; in both Bostian v. Park Natl Bank ${ }^{94}$ and Ribaudo v. Cilizens' Nat'l $B a n k,{ }^{95}$ even though the borrower in fact retained access to the pledged merchandise, the defendant bank still prevailed upon proving that no unauthorized removals resulted.96 Finally, the field warehouse companies are prone to settle out of court, primarily to keep the confidence and goodwill of the bank-

creditors"). The court also noted that CAI. Crv. CODE ANN. $\S 3440.5$, described in note 86 supra, which was not itself applicable in Heffron, only clarified existing law. Sec also Barry v. Lawrence Warehouse Co., 190 F2d 433 (9th Cir. 1951) (Arizona).

88. If, for example, the depositor did not have title to the goods he would not by depositing them in a warehouse and negotiating or transferring the receipts pass good title to the purchaser. The rights of purchasers are limited to the rights the original depositor had or had the ability to convey. UWRA $\$ \$ 41-42$ (rights of purchasers), 9, 12 (delivery obligations to receipt holder excused); First Nat'l Bank v. Petzoldt, 262 F.2d 540 (10th Cir. 1958) ; Dunagan v. Griffin, 151 S.W.2d 250 (Tex. Ct. Civ. App. 1941).

89. See Friedman, supra note 71, at $1005-06$.

90. E.g., Illinois enacted UWRA in 1907, see 3 UNIforar LAws ANN. Nxv (1959), and enacted its bulk sales act, ILL. Rev. STAT. ch. 121/2 § 78 (1957), in 1913.

91. See UCC \$§ 6-103(1), 9-111 \& comment; Billig, Article 6-Order Out of Chaos; A Bulk Transfers Article Emerges, 1952 WIs. L. Rev. 312, 320-21; 2 New York Hearings 1157.

92. In the last ten years only four of the reported cases concerning field warchouses have included an attack on the bailment's validity. See Ribaudo v. Citizens Nat'l Bank, 261 F.2d 929, 933-35 (5th Cir. 1958); Bostian v. Park Nat'l Bank, 226 F.2d 753 (8th Cir. 1955) ; Barry v. Lawrence Warehouse Co., 190 F.2d 433 (9th Cir. 1951) ; Bradley v. St. Louis Terminal Warehouse Co., 189 F.2d 818, 823 (8th Cir. 1951). All four attacks were unsuccessful.

93. See Funk, Secured Borroaning by Small Business, 13 Bus. LAw 335, 346 (1958).

94. 226 F.2d 753 (8th Cir. 1955).

95. 261 F.2d 929 (5th Cir. 1958).

96. $226 \mathrm{~F} .2 \mathrm{~d}$ at $755 ; 261 \mathrm{~F} .2 \mathrm{~d}$ at $934-35$.

The Bostian decision is criticized in Nadler, Recent Dezelopments in Bantruptcy, 30 REF. J. 39, 40-41 (1956), as an example of field warehousing being detrimental to general creditors' interests. But see Credit Research Foundation, Nat'l Ass'n of Credit 
ing community, on whom they depend for business, ${ }^{97}$ but also to prevent unfavorable precedents.

That a field warehouseman will reimburse a lender whose lien has been lost because of an invalid bailment is a generally accepted proposition, although reimbursement seems more a product of business practice than of legal obligation. ${ }^{98}$ Liability has never been compelled by a court, nor is it certain that it would be imposed if the issue were litigated. Liability for nondelivery under section 8 of URWA is conditioned upon the "absence of some lawful excuse" ;"0 section 9(a) provides such an excuse when the warehouseman has previously surrendered the goods to one "lawfully entitled to ... . [their] possession," such as a bankruptcy trustee who has successfully attacked the field-warehouse arrangement's validity. If the warehouseman is deemed to owe a duty of care to the bank, ${ }^{100}$ failure to carry out the usual field-warehousing safeguards could conceivably found a cause of action in tort. Recovery might also be predicated on a theory that the field-warehouse company warranted the legal impecca-

Men, Study on Field Warehousing, Feb. 1952, pp. 16, 31 [hereinafter cited as Study on Field Warehonsing], arguing that field warehousing assists the general creditor by, inter alia, enabling the borrower to obtain loans to pay off unsecured debts.

97. See SWEETSER 401 (field warehousing's dependence on banks' confidence); $c f$. Letter From Donald K. Miller to New York Law Revision Commission, Sept. 17, 1954, in 1 New York Hearings 735-36; Statement of Donald J. Dickens, 2 id. at 1160 (ficld warehouse companies have the confidence of banks).

98. It appears from interviews held with both the field-warehouse companies and banks, from the literature circulated by the field-warehouse companies, c.g., Miller, Scven Steps in the Protection of Loans Based on Warehouse Receipts, Bankers Monthly, Dec. 1949, p. 7; Hoover, Check List for Loans on Field Warehouse Receipts, 29 Buts. Roveat Morris Assocs. 23, 24 (1946), from the lack of cases on this issue, and from the lenders' continued use of field warehousing, that if the pledge is held invalid the lender is reimbursed from the field-warehouse companies' own funds or through their insurance coverage. Where loss arises from missing items rather than invalidity of the bailment, judicial authority exists holding the warehouseman responsible. See cases discussed in text at notes 208-22 infra. Without such assurance of reimbursement, bankers would probably not consider field warehousing worthwhile. See Letter From Donald K. Miller to New York Law Revision Commission, Sept. 17, 1954, in 1 New York Hearings 735-37; Statement of Donald J. Dickens, 2 id. at 1160.

When invalidity of the bailment is not the cause of the loss, the field warehouse companies will sometimes litigate rather than concede liability or settle, apparently fecling that the banking community does not expect them to assume this type of risk unless themselves at fault. See cases discussed at notes 208-22 infra and accompanying text.

99. Thus, the warehouseman would be excused from delivering the goods to the receipt holder if he delivered them instead to a party who had better title to them. See First Nat'l Bank v. Petzoldt, 262 F.2d 540 (10th Cir. 1958) ; Second Nat'1 Bank v. Ohio Contract Purchase Co., 28 Ohio App. 93, 162 N.E. 460 (1927).

100. In negligence actions, a usual requirement of liability is that the defendant have a duty of care towards the plaintiff, so that the tortfeasor's liability will be restricted to those persons who he could have reasonably foreseen would be injured by his conduct. See Prosser, Torts 166-68 (2d ed. 1955) ; 2 Harper \& JAMEs, Torts $\$ \S 18.1-2$, at 101527 (1956). The warehouse company apparently owes such a duty of care to the bank, since it knows the lender will be injured if its bailment is ineffective. 
bility of its services, ${ }^{101}$ or that the bank was a third-party beneficiary of a contract in which the field-warehouse company impliedly promised the borrower to establish a valid bailment, ${ }^{102}$ or that the field warehouse entered directly into an implied contract with the bank to the same effect. ${ }^{203}$ Judicial resolution of the point will probably never be required, however, since the field warehousemen publicly proclaim their liability in bank-directed advertising. Perhaps an insurance company, whose usual policy covers the fieldwarehouse company only for its "legal liability,"104 would decide to secure a court determination of its obligation to indemnify by claiming the field warehouse had failed to assert a good defense. But the present position of fieldwarehouse companies and their insurers that they will assume all risks of the bailment's invalidity, coupled with the unlikelihood of that contingency, has made field warehousing an extremely attractive security device. Of course, field warehousing's value to banks eventually hinges on the warehouseman's ability to make good on losses for which he is responsible. This may account for lenders' preference for the large, expert companies ${ }^{105}$ who ordinarily satisfy lenders' claims with little dispute. ${ }^{108}$ As a result, losses to the lender upon default of loans secured by field warehouse receipts have been relatively infrequent and small.107 Most such losses, moreover, have stemmed from the one risk which field warehousing cannot be expected to assume, since it depends upon the bankers' own judgment: insufficiency of the agreed collateral, due to original overvaluation or an unforseen drop in the market. ${ }^{10 s}$

\section{Field Warehousing in Operation: The Mechanics of the ARRANGEMIENT}

Field-warehousing practices have been developed in response to the legal requirements of a valid bailment, the policing desired by the banks, and the minimization of inconvenience desired by the borrower. ${ }^{109}$ The essential steps are the execution by the borrower and field warehouseman of a lease for the storage area and of a contract of bailment, the selection of a warehouse manager,

101. See Friedman, supra note 71, at 1011-12. See generally 1 Cossis, Costrncts $\S \S 14,25$ (1950).

102. See SWEETSER 318-21 (typical contract form). See generally 4 Conarn, Cos:TRACTS §§ 772-73, 775-77 (1950).

103. A court could infer that the close relationship between the bank and the warehouseman, see note 98 supra, and from the fact that the bank suggests to the borrower that he use the services of the bailee, that the warehouseman impliedly contracts with the bank to create a valid bailment, see generally 1 Corbrs, Contrscts \& 18 (1950).

- 104. See Peek 77-78; 1íastelion Z1-22.

105. See Mastellon 19-23; ScHNeIder 19-21; JACOBY \& SAulinter 69.

106. See SwEETser 401 (also pointing out dependence on the confidence of insurance companies in order to obtain bonding at reasonable rates).

107. See JaCoBy \& SaULnier 82; Mastellon 73-74.

108. Se JacoBy \& SaUlnier 82.

109. See Stweetser 339-48, 367; Jacoby \& Saulnier 24; 4 Collier I 70.86, at 1703 n.48 (citing cases). 
the issuance of warehouse receipts for the collateral, and the release of the merchandise to the borrower in accordance with bank-prescribed procedures. ${ }^{110}$ The process is usually underwritten by insurance, through fidelity bonds and deductible liability policies subscribed to by the field-warehouse company, ${ }^{111}$ and casualty policies obtained by the borrower. ${ }^{112}$

A key figure in the arrangement is the manager of the branch warchouse. For this position the field warehouse company ordinarily hires the borrower's former stock clerk. In his new job, he receives his instructions exclusively from the warehouse company which also pays his wages, although these are charged back to the borrower. He customarily retains his former scale of pay and benefits and his seniority status; if custodial duties do not require his full time, he can still be employed by the borrower for other work. The advantages of this practice are retention of the debtor's former methods of storing the goods and utilization of the custodian's familiarity with these to prevent inventory deterioration. ${ }^{113}$ The custodian, however, may find himself in a dilemma; he may remain subject to the influence of the borrower, to whom he must look for reemployment once the need for warehousing has passed. ${ }^{114}$ Thus, should the borrower ask him to release unauthorized goods-perhaps only for a few hours-he might find the pressure to comply irresistible. ${ }^{115}$ If unauthorized merchandise is released, the warehouse company's bailment may fail, or, at least, it will have to make good on its receipts for any undeliverable items. ${ }^{116}$ To protect themselves and the borrower, the field warehouse companies, and sometimes the banks, make frequent unannounced inspections at the storage location. ${ }^{117}$ The companies,

110. See note 5 supra and accompanying text.

111. See Mastellon 21-22; JaCoby \& SAulnier 25-26; SweEtser 373; Letter from Murray T. Wellman, Vice Pres., Lawrence Warehouse Co., to Yale Law Journal, June 16,1959 , on file in Yale Law Library.

112. Since the warehouseman is not liable for loss or injury to the goods except ditc to his negligence, UWRA $\S 21$, the parties must take out their own insurance to cover possible damage due to fires, floods, and acts of God. Mastellon 11-12; Friedman, supra note 71, at 1004; Sch NEIDER 47-51; Peek 90-93. The warehouse receipt issued by the field warehouseman does not warrant to the insured that it will keep the goods at the location specified for insurance purposes. SWEETSER 333.

113. See Jacoby \& Saulnier 26-27; Mastellon 27-28; Sweetser 310, 313; Frederuck, Using Public Warehouses 50 (1957).

114. See the argument of the Federal Reserve Board discussed in Friedman, supra note 71, at 1002-03; ScHNEIDER 23; Birnbaum, Form and Substance in Ficld Warchousing, 13 Law \& Contenp. Prob. 579, 591-92 (1948); Frederick, Public Warehouses in Distribution 14 (1955).

115. See SwEETSER 310. For cases where the custodian released goods without authorization, see Owens v. William H. Banks Warehouses, Inc., 202 F.2d 689 (5th Cir. 1953) ; Lawrence Warehouse Co. v. Twohig, 224 F.2d 493 (8th Cir. 1955); Nasif v. Lawrence Warehouse Co., 122 F. Supp. 562 (S.D. Miss. 1954).

116. But the warehouseman is not liable to the borrower-depositor if the latter expropriated the goods. New York Terminal Warehouse Co. v. Butlington, 213 F.2d 340 (5th Cir. 1954).

117. See SweEtser 314, 364-65, 373-89; Mastellon 61; Peek 74, 80 (warehousemen inspect once every 30 days). 
and their area directors, vary in the extent to which they will police each field location, depending on their appraisal of the relative expense from increased inspection versus that from undiscovered misfeasance. ${ }^{118}$

Records kept by the branch manager in administering the field warehouse ${ }^{\text {It }}$ render a valuable informational service to the lender. The large field warehouse companies submit to the parties a complete IBM report of the monthly warehouse activities. ${ }^{120}$ Such data helps a bank to determine whether the current value of the collateral is adequate to secure its loan, ${ }^{121}$ and allows it to ascertain if the borrower is stocking merchandise that is not being sold or used, and therefore perhaps poor security. ${ }^{122}$ Since the borrower's failure to pay his bills to the warehouse company will diminish the worth of the inventory as collateral-the field warehouseman receives a warehouseman's lien which is a first charge upon the goods ${ }^{123}$ - a duplicate of the bailee's invoice will enable the bank to remain informed of any arrears.

Most field-warehouse companies issue nonnegotiable warehouse receipts which specifically certify that the deposited inventory was received "for the account of and to be delivered to" the bank. ${ }^{124}$ Unlike their negotiable counterparts, delivery of nonnegotiable receipts does not represent a delivery of the goods or obligate the issuer to transferees unless the warehouseman is notified of the transfer. ${ }^{125}$ Since banks rarely plan to dispose of their field warehouse receipts, negotiable receipts, which are more easily sold, ${ }^{120}$ are seldom used. Indeed, banks prefer nonnegotiable receipts as collateral, because negotiable documents entail added risk from loss or theft ${ }^{127}$ and extra

118. In general, the warehouse companies will inspect each branch warchouse at least once every three months, and more often-as much as every few days-if it appears that unauthorized goods are being released. See Lawrence Warehouse Co. v. Twohig, $224 \mathrm{~F} 2 \mathrm{~d} 493,496$ (8th Cir. 1955) (three inspections in ten dnys did not succeed in averting loss).

119. These records include copies of the warehouse receipts, delivery releases, stock: cards, quantity-control records, valuation-control records and weekly reports. See SwEETSER 325-65; Mastellon 31-44.

120. Id. at 56, 60; SwEETSER 359-61.

121. See Mastellon 45-61; cf. note 130 infra and accompanying text. On techniques and problems in determining the value of collateral, see id. at 45-60; Credit Policy Comm'n, American Bankers Ass'n, Field Warehousing, 1958, pp. 10-11 [hereinafter cited as Credit Policy Comm'n]; SCHNEIDER 40-46.

122. Peek 9495 .

123. UWRA \& 27.

124. E.g., sample receipt reprinted in SwEETSER 327; see note 8 supra; Letter From Donald K. Miller to the New York Law Revision Comm'n, Sept. 17, 1954, in 1 New Yorl: Hearings 728.

125. UWRA $\S \S 41-42$; UCC $\S$ 7-502, 7-504.

126. See 2 WizListon, SaIES $\$ 413$ (rev. ed. 1948).

127. Peek 51. (comparison of negotiable and nonnegotiable receipts); Comm on Banking Relations, American Warehouseman's Ass'n, Warehouse Reccipts Can "Work" for You!, p. 7 [undated] (suggesting that negotiable documents in transit be insured). If a negotiable document is lost or stolen, the original holder must institute a court action and give a satisfactory bond before he can obtain the goods. UWRA \& 14; UCC § 7-601. 
difficulty in obtaining release of the goods. Under a negotiable receipt, the issuer will not release the goods without physical presentation of the receipt, ${ }^{128}$ while under a nonnegotiable receipt, goods may be released on "written authority from the person so entitled" to receive them. ${ }^{120}$ The form of a field-warehouse company's receipt is in most respects like that of a terminal warehouse. Neither type of bailee guarantees the correctness of the description of the goods; each warrants only that it has received a certain number of containers, which are said to contain the bailed merchandise. ${ }^{130}$ The lender therefore is often well-advised to ascertain for himself that the items conform to their description and, when necessary, have them checked or graded by an independent expert. ${ }^{131} \mathrm{~A}$ feature peculiar to fieldwarehouse receipts is the inclusion on the issuer's copy of the depositor's signed statement that he owns the goods, that they are not covered by a prior lien, and that he deposited them in the warehouse. ${ }^{132}$ The first two warranties do not aid the warehouse company, ${ }^{133}$ but the third protects it if the borrower fails to deliver the stated items and the warehouseman becomes liable to the bank for the difference. He will then have a claim on the warranty over against the borrower, though its value depends largely on the latter's continued solvency. ${ }^{134}$

The borrower's willingness to enter a field-warehousing arrangement largely depends upon reaching a satisfactory understanding with the bank for re-

128. See UWRA $\S \S 11-12,54$; UCC $\S 7-403(3)$; Joy v. Farmers Nat'l Bank, 158 Okla. 1, 11 P.2d 1074 (1932).

129. UWRA § $9(\mathrm{~b})$; see UCC \& 7-403(4).

130. See UWRA $\S 20$; UCC § 7-203; General Fin. Co. v. Riverside Warehouse Inc., 227 La. 270,79 So. $2 d 305$ (1955).

131. See Mastellon 12, 14; Schneider 16; Jacoby \& SAulnier 23.

132. See SwEETSER 330 (form), 371. The field-warehouse receipt also differs from a terminal-warehouse receipt in that the former includes a statement by the depositor of the value of the stored goods. This is to aid the bank in determining the value of the collateral and to aid the warehouse company in assessing the warehouse charges, which are based on the value of the goods. By this inclusion on the receipt the warchouseman, however, does not warrant that the valuation is correct, and he retains the right to inspect the depositor's sales invoices to ascertain the value of the goods. See id. at 319 (form), 327 (form), 329-31.

133. The warehouseman does not assume the responsibility for either of thesc elements. See UWRA $\$ \S 41-42$ (holder of receipt obtains the title to the goods that his transferor had or had the ability to convey) ; Insurance Co. v. Kiger, 103 U.S. 352, 356-57 (1880); First Nat'l Bank v. Petzoldt, 262 F.2d 540, 546 (10th Cir. 1958).

The bank may sue the depiositor on these warranties if they prove to be incorrect and the bank sustains a loss thereby. The practical value of this action, however, seems negligible since the damages claimed in such a suit would be any loss suffered by the bank in reliance on this warranty, i.e., acceptance of the depositor's note. In fact, the bank already has the note of the depositor to sue on and the due date of the note may bc accelerated at any time the bank learns that the depositor lacks clear title to the warchoused goods. Before it accepts the receipts, however, the bank can protect itself, to some degree, by ascertaining from the public records if the goods are covered by a prior lien. See Mastellon 12-13.

134. See Lawrence Warehouse Co. v. Best Lumber Co., 202 Ore. 77, 271 P.2d 661 (1954). 
acquiring his pledged inventory as he needs it. ${ }^{135}$ Several plans are available. Under the most restrictive scheme, the lender requires a certified check for the value secured by the items of collateral before he will sanction their release from the warehouse. ${ }^{136}$ Under a more liberal plan, the bank authorizes the borrower to withdraw a specified amount each week provided the borrower has repaid the portion of the loan represented by the previous week's withdrawal. ${ }^{137}$ The bank, instead of requiring a check or cash, may accept accounts receivable in place of warehoused inventory, thus adding flexibility to the financing arrangment. 138 Another method, termed "maintained valuation," is often used in the wholesale grocery industry or other businesses having a constant flow of inventory. Under this system, the warehouse company takes a complete inventory when it commences operations and issues one receipt covering all the merchandise. The bank specifies a monetary value that must be represented by the warehouse goods at any one time; inventory in excess of that amount may be released to the borrower and its value will be subtracted from the receipt's coverage. As he acquires new inventory he replenishes the total stock from which he can withdraw. ${ }^{130}$ A possible disadvantage from the lender's viewpoint is the danger, should the debtor go bankrupt, that deposits made within the previous four months will be held voidable preferences under section 60 of the Bankruptcy Act. ${ }^{140}$ The trustee in bankruptcy might contend that the lender received a pledge of new collateral without furnishing new value. But as long as the bank can show from the field warehouse records that the value of the merchandise never fell below the agreed sum, ${ }^{141}$ it probably would prevail on the theory that substitution of collateral is permissible. ${ }^{142}$

\section{Finld Warehousing as a Business: The Econoarics of an Ixdustry}

Field warehousing is dominated by six firms, five national and one regional. Combined, they conduct about ninety-five per cent of the six thousand field

135. See Mastellon 38-44; Lawrence Warehouse Company, Borrowing on Inventory To Finance Your Business, 1949, p. 20.

136. See Miastellon 38-41 (form of release).

137. Id. at 40-44; SwEETSER 339-45; see Nasif v. Lawrence Warehouse Co., 122 F. Supp. 562 (S.D. Miss. 1954).

138. See Bostian v. Park Nat'l Bank, 226 F.2d 753 (8th Cir. 1955); Frenewuck, Using Public Warenouses 44 (1957); Credit Policy Comm'n 12.

139. JaCoby \& Saulnier 24; Sweetser 345-48. See also Ribaudo v. Citizens Nat'l Bank, 261 F.2d 929, 934-35 (5th Cir. 1958); Bradley v. St. Louis Terminal Warchouse Co., 189 F.2d 818, 820 (8th Cir. 1951).

140. Bankruptey Act $\S 60,52$ Stat. 869 (1938), as amended, 11 U.S.C. $\S 96$ (1958); cf. Hopkins v. National Shawmut Bank, 293 Fed. 884 (5th Cir. 1923), cert. denicd, 263 U.S. 722 (1924).

141. Warehouseman's records are detailed enough to enable accurate listing of specific goods. See SweEtSer 348; JACOBY \& SAULNIER 25. See also Birnbaum, supro note 114, at $583 \&$ n.6.

142. See 3 CoLrIER $\llbracket 60.21 \&$ n.2 (collecting cases). 
warehouses which, according to industry estimates, are presently in operation. ${ }^{14 a}$ The largest firm, the Lawrence Warehouse Company, controls approximately half the market, measured either by number of locations or by volume of invenventory receipted. ${ }^{144}$ Lawrence and four other majors originally unclertook field warehousing as a supplement to their terminal warehouse business, offering the additional service of providing warehouse receipts for goods still remaining on customers' premises. ${ }^{145}$ All but Lawrence still retain close ties with terminal warehousing, which is carried on by another branch of their company or parent corporation. ${ }^{146}$ The sixth firm, however, is not an outgrowth of the storage business; American Express Field Warehousing Corporation, a subsidiary of the American Express Company, was established in $1944 .{ }^{147}$

The degree of concentration in field warehousing has increased substantially since World War II. ${ }^{148}$ In 1941, the six majors conducted three thousand warehouses out of an estimated total of five thousand; of the balance, most were conducted by terminal warehouse companies as an adjunct to their storage services. ${ }^{140}$ Today, the dominant firms conduct twice as many warehouses, while the others' share declined by more than eighty per cent, as against a rise of twenty per cent in total industry activity. ${ }^{150}$ These developments resemble those in other industries where success is largely dependent upon ability to spread risk. ${ }^{151}$ As elsewhere, the need for substantial capital and the possi-

143. SweEtSER 398-99; Letter From R. C. Schall, Chairman, Banking Relations Committee, Merchandise Division, American Warehousemen's Ass'n, to Yalc Law Journal, May 18, 1959, on file in Yale Law Library.

The five national companies are: American Express Field Warehousing Corp. and its subsidiary Wm. H. Banks Warehouses, Inc.; Douglas-Guardian Warehouse Corp.; Lawrence Warehouse Co.; St. Louis Terminal Field Warehouse Co.; and St. Paul Terminal Warehouse Co. and its subsidiary New York Terminal Warehouse Co.; the regional company is the Haslett Warehouse Co., which operates in the Pacific coast area. SWEETSER 397-98.

144. See Statement of Donald J. Dickens, 2 New York Hearings 1158-59; Letter From Murray Wellman, Vice President, Lawrence Warchouse Co., to Yale Laze Journal, June 16, 1959, on file in Yale Law Library.

145. See Jacoby \& Saulnier 12-15; Sweetser 401-02; Frederick, Punlic Warehouses IN Distribution 11 (1955).

146. See Merchandise Div., American Warehousemen's Ass'n, 1958-1959 Roster of Members, pp. 5 (Haslett), 9 (Douglas), 10 (St. Paul, St. Louis) (all listed as public warehouses); 1959 Moody's BANK \& Finance MANUAI. 885-86 (Lawrence is a subsidiary of the Lawrence Investment Corp., which no longer operates any terminal warehouses).

147. See SweEtSER 402; N.Y. Times, Aug. 1, 1944, p. 20, col. 2; id., Jan. 5, 1945, p. 21, col. $4 ; 1945$ Moody's Banks-INSURANCE-REAL Estate-INVEstanent Trusts 1053.

148. The trend to concentration had already been observed in 1941. JAconY \& SAULNIER 32.

149. Id. at 31-32.

150. Compare ibid. (1941 figures) with SwEETSER 397-99 and sources cited in note 143 supra (recent figures).

151. See Galbratth, American CaptTalism: The Concert of Countervaluind Power 35-39 (1952); Fellner, Conpetition Among the Few 17-24, 44-50 (1949). 
bility of serious loss from inexpertise have deterred outsiders from challeng. ing the leading firms. ${ }^{152}$ Only the American Express subsidiary has enterer and remained in more than twenty years; it commanded considerable financial backing and ready access to banks and insurers. ${ }^{153}$ Contrariwise, a recent attempt to launch a new company failed because of inability to obtain adequate insurance, while two terminal warehouse companies left field warehousing after suffering half-million dollar losses not covered by insurance. Other would-be entrants withdrew because of inability to attract a sufficient volume of business to make their costs competitive. ${ }^{154}$

As in other oligopolistic industries, competition among field warehouse firms is primarily in services and advertising, not in prices. ${ }^{165}$ Competition is keenest in promotional activities directed towards convincing bankers of the usefulness of field warehousing, in furnishing more detailed records and supervision, and in developing new uses for field warehousing. ${ }^{100}$ Occasionally, however, one company will cut its usual rate to obtain a contract involving relatively low costs or to secure future business. In the absence of proved collusion, the similarity in price entails no "contract, combination, or conspiracy" in restraint of trade" violative of section 1 of the Sherman Act. ${ }^{137}$ Nor is section 2-which proscribes "monopolization"158_violated by any of the companies, since none controls a percentage of the field warehousing market larg. enough to satisfy the Alcoa test. ${ }^{159}$ Even if one did, the relevant market fur purposes of section 2 could be defined as inventory financing or secured credit as a whole. If, however, field warehousing does constitute a separate line oi commerce, the limitations imposed by section 7 of the Clayton Act on further concentration in oligopolistic industries would probably bar any attempt at merger of the majors..$^{160}$

152. See SweEtSER 400-01; cf. GalBRAith, op. cit. supra note 151, at 37-39.

153. See SweErser $397,402$.

154. See id. at 401.

155. See id. at 389-96 (competition in new services); JACOBY \& S.AtzNikr 05 (prumotional activities of field warehouse companies) ; cf. GAlrraITH, op. cit. supra note 151, at 47-51, 92-99, 104-109; Comment, os YAIE L.J. 1627, 1643 (1959).

Although field-warehousing charges are similar, they are not identical. See Siverst 368-69; J ACOBY \& SAULNIER 78-79.

156. SweEtSER 389-96; cf. Jacoey \& SAULNier 65-67.

157. 26 Stat. 209 (1890), as amended, 15 U.S.C. $\$ 1$ (1958); see Atri Lix. Niri "Comss. Antitrust Rep. 36-42 (1955).

158. 26 Stat. 209 (1890), as amended, 15 U.S.C. $\$ 2$ (1958).

159. United States v. Aluminum Co. of America, 148 F.2d 416, 424 (2d Cir. 1945) (depending on the setting, "it is doubtful whether sixty or sixty-four percent would in enough; and certainly thirty-three per cent is not"). Compare note 149 supro and accompanying text (largest field warehouse company has 50\%).

160. 64 Stat 1125 (1950), 15 U.S.C. § 18 (1958); see Comment, "Substaslislly To Lessen Competition ... ": Current Problens of Horizontal Afergers, 6S YALE L.J. 1627, 1636-54 (1959). It might be argued that the relevant product market (line of commerce) for $\$ 7$ purposes is narrower than that under $\$ 2$. Compare United States v. E. I. du Pont de Nemours \& Co., 351. U.S. 377 (1956) (The Cellophane Case- $\$ 2$ case; Aexible wrapping 
The lender in most field-warehouse situations is a bank. When finance companies make advances against inventory it is usually to supplement a loan already made to a customer against receivables. ${ }^{101}$ It would seem too costly to set up a field warehouse for these secondary transactions, especially in view of the already high cost of obtaining credit from finance companies. ${ }^{102}$ In any event, the borrower would not resort to a finance company for a loan in the ordinary course of business, without first approaching a bank, ${ }^{103}$ whose ties; with the local community makes it prone to favor such transactions. ${ }^{104}$ No loan will be made unless the bank regards favorably "the financial and moral responsibility of the borrower as well as his capacity to trade."105 But the bank will also require collateral for most small business loans. ${ }^{100}$ Although inventory is not preferred as collateral, it is acceptable provided it consists of readily marketable goods with a stable value. ${ }^{167}$ In fact, many lenders never lend on any inventory other than raw materials, although some will accept finished goods. ${ }^{188}$ Because of possible decline in the value of the inventory and the expense of realizing on it in the event of default, banks limit their extension of credit to a proportion of its present worth, usually fifty to eightyfive per cent. ${ }^{169}$ Once inventory is chosen as collateral, field warehousing hats

materials, not cellophane), with United States v. E. 1. du Pont de Nemours \& Co., 353 U.S. 586 (1957) (du Pont-GM $-\$ 7$ cases; automotive fabrics and finishes, not fabrics and finishes). But the vitality of this argument may be weakened by International Boxing Club v. United States, 358 U.S. 242 (1959) ( $\$ 2$ case; championship boxing, not boxing; analogy to dis Pont-GM mentioned).

161. Financing Small Business 453.

162. Moreover, at least one major finance company has "almost never utilized field warehousing" because the "inventory financing which is preliminary to ... [its] sales finance business can usually be handled by trust receipts or similar legal structures . . . [and because its] units seldom make the limit of inventory loan for which ficld warchousing is particularly suited." Letter From Homer Kripke, Ass't General Counsel, C.I.T. Financial Corporation, to Yale Law Journal, Aug. 4, 1959, on file in Yalc Law Library.

163. See Jacobi: \& Saulivier 40-41; Financing Small Business 396, 449.

164. See id. at 396; Frederick, Using Public Warenouses 46-47 (1957); Malstcllon 1-2. The fact that commercial finance companies are less accessible and numerous may also account for the smaller number of field warehouse loans granted by them. See Financinc, Small Business 396, 449-51.

165. Credit Policy Comm'n 5; see Mastellon 48-50. See generally Fourke \& Prochnow, Practical Bank Credit (2d ed. 1950).

166. See Smith, Security Pledged on Member Bank Loans to Business, 33 FED. REserve Bet.l. 664 (1947); Mastellon 1-2; Frederick, Using Public Wankhouses 46 (1957) ; Funk, Secured Borrowing by Small Business, 13 Bus. LAw 335, 338, 343 (1958); Kripke, The "Secured Transactions" Provisions of the Uniform Commercial Code, 35 V. L. Rei. 577, 582-83 (1949) ; of. Financing Smale Business 384-85.

16\%. Sec, c.g., Jacoby \& Saulnier 72-74; Schneider 40-46; Credit Policy Commiı 10-11. See generally Gee, The Evaluation of Receivables and Inventomies (1943).

168. Credit Policy Comm'n 12; JACOBY \& SAulnier 72.

169. See Mastellon 51, 65-69 (case history) ; Jacoby \& SAulnier 72-76; Schnemper 40-46; Ribaudo v. Citizens Nat'l Bank, 261 F.2d 929 (5th Cir. 1958) (66\%\% on plumbing supplies); Lawrence Warehouse Co. v. Menary, 143 F. Supp. 883, 885 (S.D. Iowa 1956) (90\% on cattle carcasses). 
the advantages to the banker of effecting a valid pledge and ensuring that the security will not be released unless specifically authorized, without the disadvantage of increased expense, since the entire cost of the field warehouse is borne by the borrower. ${ }^{170}$ On the average, interest rates are slightly lower if the loan is secured by inventory, as in a field warehouse arrangement, than by receivables or by equipment, ${ }^{171}$ but higher than in loans secured by collateral, such as government bonds, which requires little administrative supervision. ${ }^{172}$

The typical borrower in a field warehouse transaction, as in the past, ${ }^{173}$ seems to be a relatively small business. He is usually a member of an industry in which seasonal fluctuations necessitate large working capital for short periods of time, or in which inventories constitute a major portion of total assets, ${ }^{174}$ who seeks to use the money he borrows to take advantage of trade discounts. quantity-lot prices, car-lot freight rates, or opportune purchases. ${ }^{170}$ Or, if he is a manufacturer, he may apply the loan to expenditures during peak processing periods, or while the product is curing or aging. ${ }^{178}$ Additional working capital may be also used to stabilize production schedules throughout the year, even though the selling season is short. ${ }^{177}$ Today, "almost any product that can be stored may be used as collateral for a bank loan under field warehousing," and some six hundred different items have been accepted.178 Al-

170. SWEETSER 318-21, 368-69.

171. See Cagle, Security Pledged on Busitess Loans at Member Banks, 45 FED. REServe Butz. 1114, 1121-22 (1959); Smith, supra note 166, at 672-75; Frenesick, Puaric W AREHOUSES IN Distribution 12 (1955).

172. See Cagle, stpra note 171, at 1121-22; Smith, supra note 166, at 670-73.

Some have stated that because of the firmer hold over the collateral, field warelouse loans will bear lower than usual interest rates. See Whitney, Aloders Cosruercini. Practices 665 (1958); cf. Friedman, Field ITarehousing, 42 Coluar. L. Rev. 991,993 (1942) (compared to unsecured loans). This conclusion seems oversimplified, however, because of varied factors which determine the interest rate, such as the size of the loan, the financial strength of the borrower, the administrative procedures required, and the

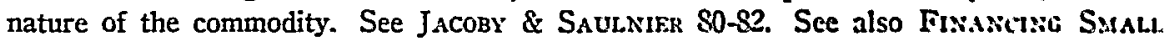
Business 387-90; Cagle, sipra note 171, at 1121-22.

173. See Smith, supra note 161 , at 673 ; JACOBy \& SAULnIER 57 . See also Fivalicisu Satall Bustness 374-81.

174. See JacoBy \& Saulnier, 58-60.

175. See Lawrence Warehouse Co., Borrowing on Inventory To Finance Your Business, 1949, p. 11; Frederick, Public Warehouses in Distarbutnng 7-8 (1955) (transportation costs); SwEETSER 369-70; Study on Field Warehousing 14-16. See generally GutharanN \& Dougall 414-56; Friedman, supra note 172, at 993-94 \& nn.16-19; SweEtSER 5-114.

176. See Lawrence Warehouse Co., Borrowing on Inventory To Finance Your Business, 1949, pp. 15-16.

177. See id. at 15, 25 (case study); Frederick, Using Public Warehousrs 51 (1957) (case study).

178. Fredertck, Public Warehouses in Distribution 11-12 (1955); see Credit Policy Comm'n 13-14 (listing commodities).

The classic example of an industry which uses field warehousing is canning; the canner 
though some borrowers have found their storage methods so improved by a field warehouse that they retain the arrangement for internal inventory control purposes even when unsecured credit is available, ${ }^{170}$ field warehousing is generally worthwhile for the borrower only when the loan it makes possible yields, profits, or savings that exceed his combined interest and field warehouse costs.

The price charged the borrower for field-warehousing services is made up of both fixed and variable components. The fixed figure covers installation and supervision. The variable charge, beyond a fixed minimum rate, is based upon the value of the goods deposited, ${ }^{180}$ that is, on the same principle as casualty insurance rates, ${ }^{181}$ and not upon criteria of space and handling which govern terminal warehouse tariffs. ${ }^{182}$ This is understandable, since the field warehouseman's business, like that of an insurer, is assuming risks; he warrants that should the lender's lien fail upon invalidation of the bailment he will reimburse the lender. ${ }^{183}$ The total charges for operating a field warehouse usually average between one and two per cent of the loan subsequently procured. ${ }^{184}$ This variation in total warehousing costs is a function of the size of the loan; since fixed charges remain constant-about 700 dollars per location ${ }^{185}$ - the smaller the loan, the higher the warehousing costs in terms of percentage of the loan amount. And, therefore, the smaller the loan, the greater the probability that warehousing costs, combined with interest charges, will exceed the loan's value and forbid the use of field warehousing. Moreover, the warehouse companies disclaim interest in accounts involving inventory worth less than a previously determined amount. ${ }^{180}$ It follows that, although field warehousing caters primarily to businesses of modest size, it is unavailable to the enterprise possessed of too little inventory and/or needing very small loans. ${ }^{187}$

must process his product within a two or three month period, during which he has to paly growers, can-suppliers, and labor. See JACOBY \& SAULxifR 14-15; Van Vlissingen, $A$ Better Look at Field Warehousing, The Burroughs Clearing House, July 1936, pp. 14 15: Friedman, supra note 172 , at 993.

179. The Government's use of field warehousing for stockpiling of strategic material in wartime is another instance of its value as a control device. See Defense Supplic Corp. v. Lawrence Warehouse Co., 67 F. Supp. 16 (N.D. Cal. 1946).

180. SWEETSER 322-23.

181. See Vance, Insurance $\$ 8$ (3d ed. 1951).

182. See Freierick, Using Publ.tC Warenouses 59-68 (1957).

183. See notes 98-108 supra and accompanying text.

184. See Sweetser 368; Jacoby \& Saulnier 79.

185. See Swertser 368-69.

186. See Lawrence Warehouse Co., Borrowing on Inventory To Finance Your Busi* ness, 1949, p. $23(\$ 5,000)$; Frederick, Using PUbLic Warehouses 47 (1957) (loans of $\$ 5,000$ to $\$ 10,000$ ) ; cf. SwEETSER $322-23$ (minimum rate is that which would be charged for a $\$ 20,000$ average monthly flow of inventory).

187. See Jacoby \& Saulnier 80; Study on Field Warchousing 18. 


\section{Field Warehousing in Contearporary Courts: Problems uf Priority aNd Loss Allocation}

Those involved in field-warehousing transactions need not concern themselves with the case law on the validity of the bailment. ${ }^{188}$ The requirements which it establishes are automatically satisfied when the routine of experienced field-warehouse companies is adhered to faithfully. Thus the two emerging areas of new field-warehouse law start from the assumption that the bailment is valid. The first arises from disputes between adverse claimants to the goods, such as their original owner and the holder of receipts or, more usually, lenders who have different security interests in the same collateral and who are competing for priority. The second concerns allocation of the loss which occurs when receipted goods are missing from a field warehouse.

Controversy between an innocent original owner and an equally blameless receipt holder will arise when the former has first surrendered possession of the goods to one who subsequently deposits them in a field warehouse, pledges the receipts to secure a loan, and eventually becomes financially irresponsible. ${ }^{189}$ Such a pledgor might have gained possession illegally, as by theit or fraud, but more usually would be a storage agent, processor, repairman. or other commercial bailee. The problem was illustrated in 1958 by First Nat'l Bank v. Petzoldt, ${ }^{190}$ where a grain elevator operator held, under a fieldwarehouse arrangement, alfalfa seed received for storage from a farmer, and pledged the receipts as security for a bank loan to be used in the elevator's business. The elevator became bankrupt, and the Tenth Circuit, in an action by the farmer to replevy the alfalfa seed from the field warehouseman, 101 had to resolve whether the loss should be borne by the farmer-depositor, the bank, or the warehouse company. The latter successfully invoked the established rule that a warehouseman does not guaranty the title to goods represented by his receipts and will be relieved from liability to the receipt holder should the seed be taken from him by judicial process establishing paramount title in another. ${ }^{192}$ The court held that such title was in the farmer, and rejected the contention that he had given the elevator company apparent authority to sell the seed and was therefore estopped to assert his title. An estoppel theory was unavailable, the court ruled, because the hank failed tu

188. See notes 65-76, 109-115 supra and accompanying text.

189. A similar problem has arisen in the liquor distilling industry when a distiller fraudulently issues more than one set of recejpts covering the aging whiskey in his own bonded warehouse. See, e.g., In re Hedgeside Distillery Corp., 123 F. Supp. 933 (N.D. Cal. 1952) ; Gould v. City Bank \& Trust Co., 213 F.2d 314 (4th Cir. 1954).

190. 262 F.2d 540 (10th Cir. 1958).

191. The real party in interest may have been a second bank, which was coplaintiff. This bank made a loan to the farmer secured by the pledge of warchouse receipts issued by the elevator. If the farmer had been unable to pay his note, this bank would have depended upon success in the instant suit for payment. The two will be treated as one, however. See id. at 542-43 \& n.2.

192. Id. at 546 . 
produce evidence of deceit or fault on the farmer's part. ${ }^{103}$ This subordination of the rights of a good faith purchaser is the most troublesome feature of the opinion; it puts lenders on notice that field-warehouse receipts may be risky collateral when their pledgor is himself a commercial bailee, and thus blocks somewhat "the end that commercial transactions may be engaged in without elaborate investigation of property rights and in reliance on the possession of property by one who offers it . . to secure a loan."104 To further that end, the minority rule, apparently adopted by the Uniform Commerical Code, fincls an estoppel in similar cases. ${ }^{105}$ Of course, the goal of free transferability in commercial transactions must be weighed against the property rights of the original owner, who is just as innocent as the bank. Since the Tenth Circuit was mindful of the farmer's property rights, ${ }^{100}$ Petzoldt may be premised on an inarticulate conclusion that the bank is better equipped to absorb the loss or, in this fact situation, that the bank was in a better position to assess the elevator's reliability.

Controversies betwen different lenders both claiming liens on the same field-warehoused merchandise will arise, for example, when a borrower obtains a loan against his inventory secured by a factor's lien and then, by pledging field receipts on the same inventory, procures additional funds from a second lender. Prior filing by the factor protects his lien from the claims of subsequent creditors, presumably including those who loaned against field receipts. But factors' acts permit a "purchaser," even with notice, to take the inventory free of the lien. ${ }^{107}$ It might be argued, therefore, that a documentary pledgee is a "purchaser," and that the holder of field-warehouse receipts should prevail, although it would seem more reasonable to restrict "purchasers" to those such as buyers in the ordinary course of business, who

193. Id. at $545-46$.

194. Gilmore, The Commercial Doctrine of Good Faith Purchase, 63 Yale L.J. 1057 (1954).

195. See Preston v. Witherspoon, 109 Ind. 457, 9 N.E. 585 (1886); 2 Wiluston, SALES $\$ 312$ (rev. ed. 1948); UCC $\$ 7-503$ \& comment 1.

Under UCC \& 7-503, if Petzoldt gave the elevator company "actual or apparent authority to ship, store or sell . . . or . . . power of disposition under this Act (Sections 2-403 and 9-307)," he would be estopped to claim the goods from a subsequtent receipt holder. But since the grain was not delivered to the bank, it could not invoke $\$ 7-205$, which permits a buyer "of fungible goods sold and delivered by a warehouseman who is also in the business of buying and selling such goods" to take free of any claim under a warelioust. receipt. See Braucher, Documents of Titre Under the Uniform Commerciai. Cont 62-66 (1958) [hereinafter cited as BraUcher].

196. [T] The transfer to Platte Valley [the elevator] was a bailment with title remaining in Petzoldt [the farmer]. The validity or invalidity of the Platte Valley receipts can in no way influence the purport of the other evidence of ownership contained in the record .... [W] fail to see how the technical validity of the receipts has any material bearing on the claim to title.

262 F.2d at 545.

197. See, e.g., Ohio Rev. Cone Ans. $\$ 1311.62$ (Page 1953); TEx. Rev. Civ. Stat. ANN. art. 5506c $\$ 4$ (1958); Gilmore, Chattel Security: II, 57 YALE L.J. 761,770 (1948). 
are unlikely to check filing records before dealing with the borrower. Should the field warehouse lender be held a "purchaser," however, the factor might also avoid loss, since his lien would shift to the proceeds of the field warehouse loan. ${ }^{198}$ In the converse situation, where the field-warehouse lender made the first advance, he clearly should prevail over factors' liens. His constructive possession of the inventory through the documentary pledge prevents any subsequent creditor from obtaining a senior security interest under the factor's lien acts. ${ }^{199}$

When trust-receipted goods are deposited in a field warehouse, the first lender would usually prevail; since trust receipts, in most jurisdictions, may be issued only on incoming stock, the entruster will almost invariably be the first lender. ${ }^{200}$ UTRA explicitly makes an exception when the borrower deposits the goods in a warehouse and receives a negotiable receipt. Under section 9(1)(a), as at common law and consistently with UWRA, "purchasers in good faith"--which includes pledgees $* 01$ - of such receipts acquire title free of the entruster's interest, even if the latter had filed notice of his financing arrangement. ${ }^{202}$ Field warehouse receipts are ordinarily nonnegotiable, however, and here an opposite result will follow. Under UWRA and at common law, the holder of a nonnegotiable receipt acquires only such title as the depositor had. ${ }^{203}$ That title was and remains subject to the entruster's security interest. ${ }^{204}$ This result is suggested by UTRA-its express provision for negotiable receipts impliedly excludes nonnegotiable documents from similar treatment-and is reinforced by the official comment to the act. ${ }^{n s}$ The fieldwarehouse lender in these circumstances is not unjustly disadvantaged. He could and should have protected himself by inspecting the filed records. .00 When the entruster fails to file, however, the guod faith field-warehouse lender prevails as one who "gives new value . . . and obtains delivery of goods."

When goods for which receipts are outstanding are missing from a warehouse, the warehouse company may attempt to shift the incidence of loss from itself to another party. The cases, none of which involve direct attacks on

198. See, e.g., New York Pers. Prop. Law \$ 45; Tex. Rev. Civ. Stat. Axit. art. 5506c, § 6 (1958); Hoxnold, Cases on Sales and Sales Financing 510 (1954). Sume states do not provide for the lien shifting to accounts receivable. Sec, e.g., Onu Rev. Coos ANx. §§ 1311.59-.64 (Page 1953).

199. See, e.g., X.Y. Pers. Prop. Law $\S 45$; Ohlo Rev. Cove Axs. $\S 1311.62$ (Page 1953); Tex. Rev. Civ. Stat. AxN. art. 5506c, § 8 (1958).

200. See note 28 silpra.

201. UTRA \& 1.

202. UTRA $\S 9$ (1) (a)-(b); see 9C UNTForM LAws ANx. 226-27 (1957).

203. UWRA $\S 42 ; 2$ WILlistoN, SaLEs $\S 427$ (rev. ed. 1948).

204. See 3 Condrt. Sile-Chat. Mort. Rep. I 5126; Commercial Credit Co. v. Peak, 195 Cal. 27, 231 Pac. 340 (1924).

205. 9C Uxiforar Laws ANw. 227 (1957) (\$ 7.iv).

206. See ibid.

207. UTRA § $9(2)$ (b). Under \& 8, the entruster's security interest is valid without filing for thirty days, but it still does not prevail against pledgces without natice who take possession prior to filing. 9C UNIFORM LAws ANw. 227 (1957) (\$7.i). 
the bailment's validity, have followed either of two patterns: caves in which the warehouseman resists liability on its receipts, and those in which he honors the receipts, but seeks to recover over against another.

In Nasif $v$. Lawerence Warehouse Co., ${ }^{208}$ a suit by a lender, Lawrence re. fused to assume full liability for the absence of receipted goods, but instead sought to leave the loss with the lender upon the borrower's default. Lawrence's efforts were sustained in part. Both the lender and lawrence had acquiesced in numerous deviations from standard field-warehonse procedures. and the court was aware that both were partly to blame for the loss. Plaintiff sued to recover from Lawrence the damage resulting from shortages in several categories of receipted merchandise. He made four claims, two founded on receipts, a third on failure to issue a receipt against deposited goods, and the fourth sounding in negligence. Lawrence successfully defended one of the claims, by showing that plaintiff had knowingly accepted a receipt for merchandise he knew was not warehoused. But Lawrence failed to prove that plaintiff had orally authorized release of the items represented by certain other receipts, and therefore did not make out its defense to the second claim. Lawrence was held not liable on the third claim, since the custodian's promise to receipt certain incoming merchandise, payment for which lender had guaranteed, did not bind Lawrence whose contract with the horrower included no provision for accepting such deposits and precluded any fee therefor. But the negligence of the custodian, whose undervaluation of goods released against some receipts diminished the stock available to satisfy others, was imputed to Lawrence; therefore, plaintiff's fourth count was successful. ${ }^{203}$ The court refused punitive damages on the ground that plaintiff's lax conduct had contributed to the deficiencies. Nasif represents a perceptive attempt to apportion loss between two parties, according to fault and other circumstances of each claim. Both parties were blameworthy for the loss of the items involved in the first claim, while neither was in the third claim; in both, the court allowed the loss to remain where it had fallen, with the lender. But the lender was not to blame for the goods involved in the second and fourth claim. while the warehouseman was; therefore the latter was held responsible. Nasif's treatment of those claims in which lender and warehouseman were equally blameworthy or equally blameless demonstrates a judicial reluctance to burden warehousemen with risks they do not assume; in deciding the first and third claims against plaintiff, the court noted that the goods there involved were not included in the computation of Lawrence's charges. ${ }^{210}$

In New York Terminal Warehouse Co. v. Bullington, 211 the depositor's fault was held to relieve a warehouse company from any liability on its receipts to one standing in the depositor's shoes, in spite of its own apparent negligence

208. 122 F. Supp. 562 (S.D. Miss. 1954), aff'd, 219 F.2d 536 (5th Cir. 1955).

209. 122 F. Supp. at $567-68$. Part of this cause of action failed because the plaintiff waived the payment of certain excess percentages for released goods. Ibid.

210. Id. at $565-67$.

211. 213 F.2d 340 (5th Cir. 1954), 33 Texas L. Rev. 523 (1955). 
in allowing the depositor to remove collateral from the warehouse. Negotiable receipts covering peanuts deposited by the borrower had been issued as collateral to a lending bank, which assigned them, and the underlying loan, to the Commodity Credit Corporation [CCC]. Later, when $\mathrm{CCC}$ demanded delivery against its receipts, eleven of them were dishonored by the field warehouse company because the peanuts they represented had been disposed of by the depositor, who shortly thereafter went bankrupt. In the ordinary course of events, the warehouse company would have paid CCC the value of the peanuts it could not deliver against the receipts; in fact it sent the CCC a letter admitting liability. ${ }^{212}$ But the bankruptcy court ordered $C C C$ to turn the receipis over to the depositor's trustee in bankruptcy, Bullington. Bullington was expected to recover on them for the estate, and the statutory priority claimed by CCC would then entitle it to receive the proceeds of such recovery ahead of all other creditors. ${ }^{213}$ But the plan went awry when the trustee's plenary suit against the warehouse company failed, upon defendant's proving that the borrower had obtained the peanuts without surrendering receipts therefor. Such a defense would have been unavailing against CCC, a holder in due course, but "the trustee stood in the shoes of the bankrupt and not in those of the Commodity Credit Corporation."214 Without the anticipated recovery, the bankrupt estate proved insufficient to pay the statutory priority in full. $\mathrm{CCC}$ was therefore allowed to regain the receipts from the trustee, and brought suit on them against the field warehouse company. In this case, United States v. New York Terminal Warehouse Co., 210 the warehouseman again prevailed, on the theory that CCC was no longer a holder in due course, and that without such status CCC was bound by the res judicata effect of the judgment against its transferor, the trustee. Although the field-warehouse company would have been liable to CCC if that agency had first sued, it was not on that account obliged to make restitution here. ${ }^{210}$

Bullington is the only reported case involving the allocation of loss for missing goods between a negligent warehouse company and a culpable depositor or his representative. The warehouseman was absolved from liability not because he did not assume it or even solely because his opponent was at fault, but, since the depositor had once enjoyed the benefit of the goods, because "equity does not require a second realization on the same asset."-17

212. United States v. New York Terminal Warehouse Co., 233 F.2d 238, 241 (5th Cir. 1956). The warehouseman's liability to CCC would of course be limited to the amount of the unpaid portion of the loan which the warehouse receipts secured.

213. 213 F.2d 343. See Bankruptcy Act $\S 64,52$ Stat. 874 (1938), as amended, 11 U.S.C. $\S 104$ (1958).

214. $233 \mathrm{~F} .2 \mathrm{~d}$ at 240 .

215. 233 F.2d 238 (5th Cir. 1956).

216. It is unclear whether the Government actually argued a restitution theory; however, the court seems to have considered and rejected the possibility: "The government must prevail ... according to established legal principles and not mercly because its failure to recover would result in unjust enrichment of the ... [warchouse company]." Id. at 241.

217. 213 F.2d at 344. 
But the ambit of the Bullington rule is small; cases in which the depositor, or those with his rights, possesses receipts will be rare. Only the bankruptcy court's action in ordering CCC to turn over the receipts to the trustee insulated the warehouseman from liability in the instant case; otherwise CCC or the lending bank, if there had been no assignment, would have successfully imposed the loss upon the warehouseman. ${ }^{218}$

When a warehouseman accepts liability for missing receipted goods, he may nevertheless attempt to shift the loss to the party responsible for the discrepency, if that party is solvent. Thus, in Lawence Warehouse Co. v. Best Lumber Co., ${ }^{219}$ suit was brought against the borrower after Lawrence had paid his bank for receipts representing the missing portion of the collateral. By proving that the missing timber was not stolen or released, Lawrence established to the jury's satisfaction that Best had not in fact deposited the full amount that its warranty to Lawrence stated. ${ }^{220}$ Best was therefore liable

218. The warehouse company may attempt to avoid liability to a receipt-holding bank for goods missing because of depositor misfeasance by replacing the shortage with new collateral. Such an attempt was made in Lawrence Warehouse Co. v. Twohig, 224 F.2d 493 (8th Cir. 1955). There, plaintiff was the buying agent for the depositor, a meatpacker, who was able to pay for each shipment only by promptly field-warehousing the slaughtered carcasses and pledging the receipts for a bank loan before plaintiff's draft was presented for payment. The depositor, in collusion with Lawrence's custodian, frequently removed carcasses from the warehouse, without having redeemed the receipts or obtained the bank's authorization. At one point a shortage of at least one hundred carcasses existed, but Lawrence averted liability to the bank by issuing no reccipts against the next one hundred carcasses placed in its warehouse. But, by avoiding liability to the bank, Lawrence found itself liable to plaintiff. He remained unpaid for the last shipment and sued Lawrence; he claimed that Lawrence had unjustly enriched itself at his expense. Since the court held that the depositor had a fiduciary duty to plaintiff, it held Lawrence liable by applying Restatenent, Restitution $\$ 138(2)$ (1937): "A third person who has colluded with a fiduciary in committing a breach of duty, and who obtained a benefit therefrom, is under a duty of restitution to the beneficiary." The warehouseman probably would not be held liable to an ordinary seller in a similar situation, since a buyer has no fiduciary obligation to an unpaid seller. See REstatenrent (SECond), TRUSTS § 12 (1959); 1 ScorT, TRUSTS $\$ 12.1$ (1956). Nor could an unpaid seller in a credit transaction obtain relief from the warehouse company under a conversion or replevin theory, since he would no longer have any interest in the goods once they are delivered. See UnIForM SALES ACr $\$ \$ 52-65$ (rights and remedies of unpaid seller). But if cash payment were contemplated at delivery but not received, this would constitute "larceny by trick or device" and title to the goods would remain in the seller, 3 Wrulsston, SAles $\S 511$ \& n.15 (rev. ed. 1948); see Gilmore, The Commercial Doctrine of Good Faith Purchase, 63 YALE L.J. 1057, 1060-62 (1954), who could probably regard appropriation of them by the warehouse company to avert liability to a bank as a conversion. But this possibility will probably remain in the realm of speculation, since a buyer who field-warehouses incoming stock but nonetheless contemplates cash payment for that stock probably does not exist outside of a commentator's footnote.

219. 202 Ore. 77,271 P.2d 661 (1954).

220. See id. at $92-93 ; 271$ P.2d at $667-68$.

The warehouseman also claimed recovery under an indemnity agreement contained in his contract of bailment with the borrower. The court denied recovery on this claim since it considered the indemnity not to extend to missing goods but only to losses duc 
on the warranty to reimburse the field warehouseman's loss. In Ua'cis 2 . IIillian $H$. Banks Warehouses, Inc., 21 a field warehouseman, having paid a settlement in compromise of a suit on its receipts, blamed its loss on the negligence of the custodian. Banks therefore sued on the fidelity bond executed by the custodian's sureties. 202 Overruling their defense that the field-warehouse company was itself negligent in failing properly to instruct the custodian in his duties, the court enforced the terms of the bond.

The foregoing cases, which are probably representative of the type of field warehousing litigation that will arise in the future, all demonstrate a judicial willingness to place the loss resulting from missing goods un someone other than the warehouseman. Arguably, the warehouseman should be held fully responsible for all losses. The difficult task of determining comparative fault would be avoided; the warehouseman, through his agent, the custodian, is always at fault in these cases in not adequately policing the bailment. Mureover, since the warehousemen are insured, the loss would be borne by the industry in the form of higher premiums. But such an argument goes unl: part of the way. The cost of higher premiums would probably be passed un to all field-warehouse users through higher charges. And it is not the warehouse company itself which is at fault, but rather the stock clerk-custodian. Ui course, the warehouse companies could engage completely independent fulltime custodians, but such a practice would greatly increase the cost of fiely warehousing. These considerations prompt the conclusions that the Nusi! court properly refused to impose upon the warehouse company in that case it liability which it did not assume, and that Best and the theory behind Bullin!yton are correct in placing the ultimate loss on depositors who caused the discrepency, even if equitable considerations of double benetit are disregarded. Similarily, if Nasif is a fault case and not an assumptivn-of-risk case, placing the loss on a blameworthy lender also seems proper. In this manner, absorption of loss by all who use field warehousing will not be forthcoming. Rather it will be borne by those who cause it. If the party at fault is unavailable. however, and the contest is between the warehouseman and an innocent party. the former seems best equipped to assume responsibility.

\section{Field Warehousing in Motion: Secured Tr.dDe Credit}

Field warehousing has recently expanded the scope of its operations into the area of manufacturers' extension of trade credit to dealers. ${ }^{203}$ Trade credit,

to physical damage to the collateral. Id. at $82-86 ; 271$ P.2d at 663-65. Disappearance of goods is, however, one of the very types of loss that the field-warehouse cumpanies try to guard against by the insertion of the indemnity provision in their bailment contracts.

221. 202 F.2d 689 (5th Cir.), cert. denied, 346 U.S. 813 (1953).

222. Id. at 691 . The sureties were the officers of the corporate depositor, who were required to make such a bond when they changed their business from a partnership to a corporation.

223. See SweEtSer 391-94; Study on Field Warehousing 25-31; Frenesick, Pugus WAREHOUSES IN DISTRIBUTION 12-13 (1955). In 1941 similar credit arrangements oecu- 
although given insufficient recognition in studies of financing, is a major source of the credit available to small business. ${ }^{224}$ It has greatly increased in the last decade through a wide variety of new devices, added to the older methods of consignment sales and of unsecured trade credit with discounts for prompt payment.225 Some manufacturers, wary of furnishing dealers whose credit rating is not high with a large volume of goods on open credit or on consignment, adopted the expedient of shipping directly to a terminal warelouse.:تv There, they thought, goods unpaid for would remain under their control while still close to the dealer's market. This financing method often proved uneconomical, however; the dealer's storage space was unused, and transportation charges were incurred when goods were moved from warehouse to dealer. ${ }^{227}$ These disadvantages would be averted if a field warehouse werte established on the dealer's premises. This field-warehousing technique-which this Comment shall term "secured trade credit"-is rapidly becoming a significant portion of total field-warehousing operations. ${ }^{228}$ It is most popular with manufacturers of appliances having a seasonal demand, such as fans and airconditioners, ${ }^{220}$ but is also used for other consumer durables, such as typewriters and refrigerators, and for raw materials. 230

A field warehouse located in the dealer's storeroom permits the manufactur er either to ship to the dealer while requiring him to hold the goods in the field warehouse and remit the receipts (plan one), ${ }^{231}$ or to ship directly to "himself"

pied $2.6 \%$ of the number of warehouses being operated by four leading companics. J Aronv \& SAULNIER 40-41. For present extent see note 228 infra.

224. Financing Small Business 482. On interbusiness and trade-credit financing. see generally Andrews, Friedland \& Shapiro, Working-Capital Financing of Sinall Business, 24 Law \& Contensp. Prou. 68, 79-85 (1959); Guthusnne \& Dougall 436-56.

225. The new devices include financing affiliates, longer-term credit, supplying necessary plant and equipment. See Financing Sual. Business 489-98.

226. See Study on Field Warehonsing 26-27 (study of York Mig. Co.) ; Swmzitsen $391-92$.

227. See Study on Ficld Warehousing 27 ; Sweetser 392-94; Frederick, Punlac WakEHOUSES IN Distribution 12-13 (1955).

228. See 2 New York Hearings 1160. Various officials have estimated that it constitutes between $10 \%$ and $40 \%$ of total field-warehousing operations. See also letters cited in notes 236-38 infra.

229. See Study on Field Warehousing 26; SwEETSER 391.

230. See Major Appliance Co. v. Gibson Refrigerator Sales Corp., 254 F.2d 497 (5th Cir. 1958) (refrigerators and air conditioners); Lawrence Warehouse Co. v. Fidelity Trust Co., Civil No. 15219, W.D. Pa., June 7, 1959 (baies of cotton linters); Sweerser 391.

231. See Lawrence Warehouse Co., Secured Distribution Agreement-Plan 1, copy on file in Yale Law Library (two-party agreement between buyer and seller) (reprinted in Major Appliance Co. v. Gibson Refrigerator Sales Corp., 254 F.2d 497, 500 n.5 (5th Cir. 1958)). In discussing secured trade credit, this Comment will focus upon the procedure used by the Lawrence Warehouse Company, which appears to be representative of all the warehouse company plans. See, e.g., Douglas-Guardian Warehouse Corp., Travelling Credit; American Express Field Warehousing Corp., What's New in Selling and Credit, April 1956; both circulars on file in Yale Law Library. 
in care of the warehouseman (plan two). ${ }^{232}$ Under either plan, provided the bailment with the field warehouseman is valid, the manufacturer retains effective control of the warehouse's contents, under the policing of an independent third party, while the dealer has ready access to the goods as soon as he is in a position to pay for them. The manufacturer who can safely distribute to a chain of dealers in this manner will be able to level out his production schedule, transfer finished products directly from assembly line to dealer, and acquire detailed information useful to his sales and credit departments. These advantages should offset the field warehouse's cost, which the manufacturer may either bear himself or pass on to the dealer. ${ }^{233}$ Variations are possible-several manufacturers can share the facilities of one field warehouse or discounts may be offered during certain slow periods to dealers willing to stock and fieldwarehouse goods at that time ${ }^{234}$-and the name given the scheme varies: "Secured Distribution,"235 "controlled credit distribution," "330 "traveling credit,"257 or "controlled inventory plan." 238

Since merchandise shipped under plan two is the sole property of the manufacturer, he may later remove it from the warehouse and send it or sell it to anyone else he chooses. ${ }^{239}$ Under this plan, however, he must accept all the risks of market fluctuation and of destruction of the goods, and might have to qualify to do business in the state of the warehouse location and pay its franchise and personal property taxes. ${ }^{240}$ Conversely, plan one shifts these risks and obligations to the dealer, ${ }^{241}$ but the manufacturer, lacking title, has less protec-

232. Lawrence Warehouse Co., Securcd Distribution Agreement-Plan 2, cony on file in Yale Law Library (tripartite agreement among manufacturer, dealer and warehouseman).

A third plan is available although infrequently employed. It differs from plan 1 in that the dealer himself pledges the receipts, rather than remitting them to the manufacturer, and uses the loan to pay the manufacturer; but such bank credit will be unavailable unless the manufacturer agrees to repurchase unsold contents of the field warehouse, and thus insures the worth of the bank's collateral. See Study on Field Warchousing 29.

233. See Sweetser 392-94; Fredertck, Purlic Warerouses in Distrubution 13 (1955).

234. Frenerick, Public Warehouses in Distribution 12-13 (1955).

235. A registered service mark used by the Lawrence Warehouse Co. U.S. Pat. Off. Reg. No. 612791, Sept. 20, 1955.

236. Used by the New York Terminal Warehouse Co. See Letter From Thomas Clines, Vice Pres., to Yale Law Journal, June 16, 1959, on file in Yale Law Library.

237. Used by the Douglas-Guardian Warehouse Corp. See Letter From Harry D. Hamilton, Public Relations Director, to Yale Law Jounsal, June 17, 1959, on file in Yale Law Library.

238. Used by the St. Louis Terminal Warehouse Co. See Letter From Henry D.

Bugg, Vice Pres., to Yale Law Journal, July 22, 1959, on file in Yale Law Library.

239. See SWEETSER 392-93.

240. See id. at 394. On the general problems involved in doing business in a forcign state, see Comment, Foreign Corporations-State Boundaries for Notional Business, 59 Yale L.J. 737 (1950) ; Roesken, The Property Factor in State Franchise Taxation, 24 TAXEs 1043 (1946); Note, 24 U. Cinc. L. Rev. 95 (1955) (tax on warchoused goods belonging to a non-resident corporation).

241. See SwEETSER 394. 
tion in the event of the dealer's inability to pay or his transfer of the goods in breach of his agreement. ${ }^{242}$ His security interest will not attach until receipts are issued to him, while the warehouseman will not accept responsibility until the goods are deposited. ${ }^{243}$ Thus, since the dealer has possession for purposes of transit, one of his creditors may levy on the goods during that period. Or, the dealer, instead of warehousing the goods, may sell or pledge them to an innocent third party. The manufacturer may attempt to protect himself against these possibilities by specifying in the contract of sale that the dealer shall have no right, title, or interest in the goods until they are deposited in the warehouse and receipts issued for them to the shipper. ${ }^{244}$ Title would then remain in the manufacturer as conditional vendor under section 20 of the Uniform Sales Act, so that he would prevail over attaching creditors of the dealer or bona fide purchasers from him. ${ }^{245}$ But this restlt would not obtain in those states which have adopted the Uniform Conditional Sales Act, or a similar statute, which requires recording to protect the seller's interest from third parties once the goods are in the buyer's possession. ${ }^{240}$ Creditors and innocent purchasers could then take free of the seller's claims. Nevertheless, the manufacturer's risk of loss would be slight. Even if a creditor learned of a shipment and aroused the sheriff in time to attach the goods before they reached the warehouse, the manufacturer could still prevail by filing the appropriate form of conditional sales contract within the ten days allowed for retroactive recordation, ${ }^{24 \tau}$ or by obtaining a factor's lien. ${ }^{248}$ A more important precaution for the manufacturer would be the insertion in his contract with the dealer of a standard clause providing simplified remedies on default. ${ }^{240}$

242. Once title has passed to the buyer under plan 1, the shipper must repossess the pledged goods under usual pledge-default procedure. Major Appliance Co. v. Gibson Refrigerator Sales Corp., 254 F.2d 497 (5th Cir. 1958). This is more cumbersome than simply diverting the merchandise elsewhere under plan 2. See also SweErsen 394; Lawrence Warehouse Co., Secured Distribution Agreement-Plan 1, cls. 1-3. Under either plan, the dealer must transport the goods from the carrier to the warehouse since the warehouseman is not equipped or willing to do it, see notes 243,250 infra.

243. Lawrence Warehouse Co., Secured Distribution Agreement-Plan 1, cls, 1-3. Until goods are deposited, the warehouseman is not liable to the manufacturer under either plan: Under plan 1 he has no contractual relationship with the shipper until the warehouse receipts are issued; under plan 2 the agreement explicitly states that he should have no liability until the goods are deposited.

244. See Lawrence Warehouse Co., Secured Distribution Agreement-Plan 1, cl. 2.

245. 2 Williston, Sales $\$ \$ 324-326 a$ (rev. ed. 1948).

246. Uniform Conditional Sales Act $\$ \S 4-5$. The UCSA has been adopted in 12 states. 2 Uniform Laws ANn. 7 (Supp. 1958); see 2 Williston, SAles $\$ \$ 327.2 \$$ (rev. ed. 1948). See also 1-2 Condit. Sale-Chat. Mort. Rep. (listing other state statutes).

247. See Uniform Condittonal Sales Act $\$ 5$.

248. See, e.g., New York Pers. Prop. Law § 45; Ohio Rev. Code ANn. \$\$ 1311.59. 64 (Page 1953); Tex. Rev. Civ. Stat. Ann. art. 5506c (1958); Gilmore, Chattel Security: II, 57 YALE L.J. 761, 770 (1948).

249. If he inserted in his contract with the dealer the standard pledge remedy clause-which is lacking in the Lawrence Warehouse Co. Agreement-the manufacturer 
Under secured-trade-credit plan two, the shipper would prevail over all the dealer's creditors. They would have nothing to attach, since their debtor has no interest in the goods. The goods normally pass through the dealer's hands in the course of transportation to the field warehouse, however; he may then have the opportunity to sell them to an innocent purchaser. ${ }^{250}$ In such a situation, although the cases are conflicting, a court would probably hold that the shipper prevails. The dealer's possession gives him no title to transfer while his contractual authority gives him no power to sell on the shipper's behalf.251 On the other hand, the manufacturer may be held estopped; the argument that one who entrusts merchandise to a dealer in such goods is bound by the latter's exercise of his apparent authority to sell is being increasingly accepted. ${ }^{252}$ Here, however, as under plan one, the dangers of such a sale do not appear substantial. Since the relationship between the parties is probably a continuing one, good faith business dealings could normally be expected on both sides. Prolonged deception should be impossible, since a failure to field-warehouse the goods would soon be revealed by nonarrival of the anticipated receipts.

In most respects, secured-trade-credit field-warehouse arrangements resemble standard procedures. The chief administrative problem peculiar to the new device arises from unauthorized removal of goods. Unlike standard operations, in which most banks will permit the borrower to deposit any marketable goods of sufficient value to replace those which might have been improperly removed, the manufacturer wants only his goods in the warehouse. Since the manufacturer would hesitate to ship additional items without being paid for those illicitly removed, the field warehouseman will find it harder to avert liability for shortages. As a result, the charges for secured trade credit are slightly higher than those for standard field warehousing.

\section{Field Warehousing Under tile Uniforar Comarercial Code: The IMPACT OF StatuTORY Reforar}

Two articles of the Uniform Commercial Code alter the legal framework within which field warehousing operates. Article 7 attempts to reword UVWRA and codify its case-law interpretation. ${ }^{253}$ But article 9 fundamentally revamps

would not be forced to use the cumbersome common law pledge remedies which were held necessary under Lawrence Plan 1 in Major Appliance Co. v. Gibson Refrigeratar Sales Corp., 254 F.2d 497, 499 n.5 (5th Cir. 1958). See also Sweersea 129, 134-35, 138-39 (forms of pledge agreements).

250. Lawrence Warehouse Co., Secured Distribution Agreement-Plan 2, cls. IIIII (explicitly appointing the dealer as the Supplier's agent to "handle and transport" the goods from the carrier to the warehouse).

251. See 2 Williston, Sales $\$ \S 311-16$ (rev. ed. 1948) (collecting cases).

252. See, e.g., Zendman v. Harry Winston, Inc., 305 N.Y. 180, 111 N.E.2d 871 (1953); UCC $\$ 2-403 \&$ comment 2.

253. See Coogan, Article 9 of the Uniform Commercial Code: Priorilics Among Secured Creditors and the "Floating Lien," 72 HaRv. L. REv. 838, 843 \& n.21 (1959); Gilmore, The Secured Transactions Article of the Commercial Code, 16 Law \& Custear. 
the law of chattel security ${ }^{254}$ and may, therefore, effect corresponding shifts in the market for field warehousing. ${ }^{265}$ Some commentators predicted that article 9 , by providing a method for creating a lien on a shifting stock of inventory without the intervention of a field warehouseman, ${ }^{250}$ would cause the

ProB. 27, 28 (1951); UCC \& 7-101, comment. See generally Braucher, In re Article 7, 28 TEMr. L.Q. 564 (1955); Braucher, The Uniform Commercial Code-Documents of Title, 102 U. PA. L. Rev. 831 (1954) ; Littleton, Article 7: Documents of Title, 15 U. Pirr. L. REv. 595 (1954).

The American Warehousemen's Association, Merchandise Division, opposed enactment of article 7 because it felt that the adoption of the article would disrupt the existing uniformity in the law of warehouse receipts. See $1 \mathrm{New}$ York Hearings 673-75, 682-83; Letter From Charles O. Butler, Chairman of the Uniform Commercial Code Committee of the Merchandise Division, American Warehousemen's Association, to the Yale Laze Journal, May 12, 1959, on file in the Yale Law Library; para. 2, note 271 infra. The change proposed by article 7 which most perturbed the field warehousemen was $\S 7-209$, which as originally adopted limited a warehouseman's lien against goods stored on a nonnegotiable receipt to the storage charges for the particular items enumerated in the receipt. See UCC $\$ 7-209$ (1.952) ; 1 Nezv York Hearings 728, 731-32. Under UWRA \& 28 his possessory lien had applied "against all goods, whenever deposited, belonging to the person who is liable as debtor." Under the Code proposal, the field warehouseman would lose his lien each time he released goods deposited by the debtor. Section 7-209 was amended so that the ficld warehouseman can obtain a lien for his total accrued charges, against the items covered by aly one receipt, provided "it is stated in the receipt that a lien is claimed for charges and expenses in relation to other goods." UCC $\$ 7-209$; see NATIONAL Conference of CoMmisSIONERS ON UNTFORM STATE LAws, ALI, 1956 ReCOMIMENDATIONS OF THE EDITORIAl. BOARD FOR THE UNIFORM COMMERCIAL CODE 202 (1957) [hereinafter cited as 1956 UCC ReCoMMENDATIONS]. The result is that the warehouseman can secure a general lien by specilying it on his receipts. But the standard form of field warehouse receipt currently in use does not appear to satisfy the Code's notation requirement. The receipt form presently used states: "The Warehouseman has a lien for storage, handling and other charges as set forth in contract and lease with industry served." Reproduced in SWEETSER 332; for a similar form, see Mastellon 36. To satisfy the Code's notation requirement some statement of the fact that a general lien is claimed on all goods deposited by the debtor seems necessary. Sec BRAUCHER 43-44.

The substantive shift in article 7 which will perhaps most affect field warchousing arises from \$ 7-503's provision for resolving conflicting interests in the same warehoused goods. See id. at 62-65; N.Y. Law Revision Comm'n, Study of Uniform Commercial Code, Article 7-Warehouse Receipts, Bills of Lading and Other Documents of Titli, N.Y. LEG. Doc. No. $65(\mathrm{H})$, at 1843-48 (1955) [hereinafter cited as N.Y. STuvy or ARTICLE 7]. See also notes 289-300 infra and accompanying text. The section implies that a bank acquiring a pledge of field-warehouse receipts will prevail over an original owner who "delivered or entrusted" the goods to the pledgor with actual or apparent authority to store them in a field warehouse, see UCC $\$ \S 7-503(1)$ \& comment, $2-403$ (definition of "entrusting"), and would reverse the case law result illustrated by First Nat'l Bank v. Petzoldt, 262 F.2d 540 (10th Cir. 1958), see notes 190-96 supra and accompanying text.

254. See, e.g., UCC § 9-101, comment; Gilmore, The Secured Transactions Article of the Commercial Code, 16 Law \& Contranr. ProB. 27 (1951); Kripke, Thic "Sccurrd Transactions" Provisions of the Uniform Commercial Code, 35 Vo.. L. REv. 577 (1949).

255. See Everett, Securing Security, 16 LAw \& Contearp. ProB, 49, 56 (1951).

256. See UCC $\$ \S 9-204,9-205$. 
industry's death. ${ }^{257}$ But other observers maintained that field warehousing would survive as a method of lender control. ${ }^{258}$ Five years' experience in Pennsylvania, where, after an initial post-Code decline, field warehousing apparently regained and then increased its volume, correct. Conscious that the Code can afford no factional assurance that the collateral will remain unimpaired, bankers who wish to police their loans beyond minimum statutory standards 200 will utilize the field warehouseman both to guard and guarantee against dissipation. ${ }^{201}$ His receipts and reports, moreover, will enable the lender to keep apprised whether his loan was adequately secured or not, while no other security method will throw so much of the risk of loss off the lender on to a third party without requiring removal of the collateral from the buyer's premises. And experienced field-warehouse lenders will be reluctant to abandon control procedures that have worked satisfactorily in the past. ${ }^{262}$

A security interest in field-warehoused commodities can be created and perfected under the Code through the same procedures traditionally used in nonCode jurisdictions. It will attach when there is a written agreement to that effect, value is given, and the debtor has rights in the collateral;203 these requirements are met by the usual form of bank-borrower agreement that inaugurates a field-warehousing arrangement.. ${ }^{204}$ And a security interest in fieldwarehoused goods may be "perfected" against third parties ${ }^{205}$ in three alternative ways provided by section $9-304(3)$; by "issuance of a document in the name of the secured party or by the bailee's receipt of notification of the secured

257. See Everett, supra note 255, at 56; Gilmore, supra note 254, at $41 \& \mathbf{n} .62$ (damage already begun by factor's lien acts).

258. See UCC $\$ 9-305$, comment 2 (1952 Draft) ; Kripke, Arficle 9: Sceured Transactions Under the Uniform Commercial Code in Pemsylzania, 15 U. Prrt. L. RE. 603, 606-07 (1954); Robinson Commercial Lending Under the Uniform Commercial Code, 73 Banking L.J. 77, 80 (1956); Mlass. Bankers Ass'x, Bankers Miasual ox the Uniforar Colngercial Code 152 (1958); Pa. Bankers Ass'x, Penssyluania Bantss AND the UnTrorm CoMmrercial CODE 32-33 (1954).

259. See Letters From R. C. Schall, St. Paul Terminal Warchouse Co., June 1, 1959; Thomas Clines, New York Terminal Warehouse Co., June 16, 1959; Harry D. Hamilton, Douglas-Guardian Warehouse Corp., June 17, 1959; Henry D. Bugg, St. Louis Terminal Field Warehouse Co., July 22, 1959, to the Yale Laz" Journal, on file in the Yale Las Library.

260. See UCC \& 9-205.

261. See Kripke, supra note 254, at 606-07.

262. See MAss. Bankers Ass'n, op. cit. sutpra note 258, at 149.

263. UCC $\$ 9-204$.

264. Banks use their regular loan agreements in making advances secured by lieldwarehouse receipts. See SwEETSER 127-43 (bank loan forms exhibited). New bank: luan forms have been devised for use with the Code. Mass. Bankens Ass'r, op. cit. supra note 258 , at $205-12,219-21$.

265. See UCC $\$ 9-301$; Birnbaum, Article 9-A Restatement and Rerision of (hatlel Security, 1952 Wrs. L. REv. 348, 368-69. The buyer in the ordinary course of business whe purchases goods covered by a perfected security interest takes free of the secured party's interest. UCC $\S \$ 9-307,1-201(9)$ (definition of "buyer in ordinary course of business"). 
party's interest or by filing as to the goods." ${ }^{266}$ Standard field-warehouse pracktice achieves perfection under each of the first two alternatives, since upon deposit of goods the custodian will issue receipts specifically stating that the goods are received for the lender's account and are to be delivered to him, while the warehouseman has from the beginning been notified of the lank's interest.

The 1952 draft of the Code, in force in Pennsylvania until amencled in $1959,{ }^{267}$ did not contain these alternative methods of perfection; rather, its section 9-305(2) permitted security interests in field warehoused goods to be perfected only by filing. ${ }^{208}$ The draftsmen, regarding field warehousing as one more form of inventory financing in which the merchandise remains at the borrower's place of business, treated it no differently from any other. ${ }^{200} \mathrm{By}$ filing, the lender perfected his security interest whether or not a valid bailment existed. ${ }^{270}$ Although 9-305(2) might have saved the field-warehouse companies money, since invalidity of their bailment would not itself cause a loss they must reimburse, they nevertheless opposed adoption of the section. ${ }^{271}$ They claimed that it was discriminatory because security interests obtained through the pledge of terminal-warehouse receipts were perfected without recordation. that the burden of filing would make field receipts less commercially acceptable than those issued by other warehouse companies, ${ }^{272}$ that the section's worling left it uncertain which holders of field receipts must file, ${ }^{273}$ and that bankers were satisfied with the status quo. ${ }^{274}$ Indeed, bankers did object to the trouble of discerning between terminal and field receipts. ${ }^{275}$ 'The warehouse companies' efforts culminated in the deletion of the mandatory filing provision, and its replacement by section 9-304(3) under which filing became one alternative

266. UCC $\$ 9-304(3)$. A fourth method is provided by UCC $\$ 9-304(5)$; see note 306 infra and accompanying text.

267. Pa. Laws 1959, Act 426, §§ 7-205(2), 9-305(2).

268. UCC $\S 8$ 7-205(2), 9-305(2) \& comments (1952).

269. UCC $\$ \S 7-205(2), 9-305(2)$, comments (1952); Gilmore, supra note 254, at 41: Birnbaum, sutpra note 265 , at 369 n.96.

270. UCC $\S 8-205(2), 9-305(2)$, comments (1952); Note, 71 Harv. L. Rev. 674, 685 (1958).

271. 1 Neze York Hearings 735-39, 715-16; 2 id. at 1158-61.

This same filing requirement appeared in article 7 . UCC $\$ 7-205(2)$. The field warehousemen's opposition to article 7 may also have stemmed in large part from their dislike of these filing provisions.

[T] he opposition [to article 7] seems to rest primarily on a claim that present law is satisfactory. It is pussible that a good deal of the force behind this opposition arises from ... section 7-205(2), which newly subjects "field warehouse" arrange" ments to a requirement of public filing.

Memorandum by Professor Robert Braucher, for the New York Law Revision Commi sion, August 1954, in 1 New York Hearings 714, 715-16.

272. See 1 id. at 735-39; Note, $71 \mathrm{H}_{\mathrm{ARN}}$. L. REv. 674, 685-86 (1958).

273. 1 New York Hearings $735-39 ; 2$ id. at $1158-61$.

274. 1 id. at 735-36.

275. 1956 UCC Recommendations 199-200; Note, 71 Harv. L. Rev, 674, 685-86 (1958). 
means of perfection. ${ }^{276}$ Perhaps an amendment requiring the field-warehouse companies to file would have been preferable to repeal.977 In this manner, several of the warehousemen's objections to 9-305(2) would have been overcome, while, consistent with article 9's deemplasis of "differences in rules and results based on the form of security device used,"278 all security interests in goods on the borrower's premises would have been perfected in the same way' and revealed in the same file. Even under 9-304(3), however, banks holding field-warehouse receipts are well advised to record their interest, to protect it not only against possible invalidity of the bailment but also against intervening priorities in incoming inventory.

Of the alternative methods of perfection offered by 9-30+(3), only filing will ensure that the field-warehouse lender does not unknowingly accept collateral already subject to a prior perfected security interest. For example, banks operating under the usual unrecorded field-warehousing arrangement $=-24$

276. See 1956 UCC Recomarendatioxs $199-200 ; 279-80$. The draftsmen alsu made a corresponding change in $\$ 9-205$ adding a sentence to make it clear that when perfection is by possession instead of filing,

the requirements of possession are not watered down .... In other words, where the security interest is perfected by filing, the secured party may allow the debtur to use [the] ... collateral without invalidating the security interest .... But in a ... warehouse operation, similar freedom would negate the requisite actual and exclusive possession of the ... bailee.

Id. at $269-70$.

277. See 2 New York Hearings $1178-79$ (testimony of Professor Grant Gilmure). But cf. Note, 71 HARv. L. REv. 674, 686 (1958) (approving deletion).

If the field-warehouse companies had been required to file, a corresponding change would have had been necessary in the filing requirements of $\S 9-402$ which contemplates only agreements filed by the secured party. It would have been most efficient for the warehouseman just to file a statement naming the person on whose premises the warehouse was located. Anyone desiring further data on the borrower-bailor could ask the warehouseman to furnish the names of receipt holders who, under \$ 9-208, would have had to inform the questioner of their advances to the debtor. If the warehouseman neglected to file, thus leaving unperfected the interest of the lender, the latter wivuld still be protected since he could hold the warehouseman liable on his receipts or firr negligence. If the deposited goods were under a secured-trade-credit plan 2 arrangement, the receipt holder-manufacturer would inform anyone inquiring as to his interest that the goods belonged to him and not to the party on whose premises the warehause was luated.

Finally, if goods deposited in a field warehouse were sold to another party, whu left them there and pledged the receipts for a loan, no filing would be required. The ware. house in this case, not being on the debtor's prenises, is just like a terminal warthuure. Under old UCC §§ 7-205(2), 9-305(2) (1952), filing was only necessary if the fichl warehouse was on the debtor's premises. For examples of this type of field warehousing operation, see 1 New York Hearings 738; 2 id. at 1159-60.

278. Coogan \& Bok, The Impact of Article 9 of the Uniform Commercial (inds am the Corporate Indenture, 69 Y ALE L.J. 203, 205 (1959).

279. Recording is not required for field warehouses in non-Code stater. Sie nnete62-63 supra and accompanying text. But lenders occasionally elect to confurm their hiels!warehouse loans to meet factor's lien act requirements, which usually include tiling, tu obtain an extra measure of protection in case the bailment is declared invalicl. 
commonly permit the release of inventory if other items are substituted therefor. But this "maintained valuation" formula for keeping adequate collateral always on hand 280 is vulnerable when-as is particularly likely in Code states ${ }^{281}$ - the borrower's supplier or other creditor has perfected a security interest in the substituted inventory before its deposit in the field warehouse. ${ }^{282}$ If the bank has not filed a financing statement covering after-acquired collateral, it would not be entitled to notice from a supplier or creditor unaware of the bank's role. ${ }^{283}$ The bank, unless it periodically checks the filing records, is therefore likely to accept substituted collateral without knowledge of the perfected encumbrance. On the other hand, had the bank recorcled a notice of its intent to finance, the only security interest which could be senior to the bank's would be that of the holder of a purchase-money security who had informed the bank that he was acquiring one in a specified type of inventory before the debtor receives possession. ${ }^{284}$ Thus informed, the bank would not accept deposits of such inventory as collateral, even if the borrower falsely warranted that his title was unencumbered. The foregoing results are premised on the Code's basic priorities provision, section 9-312. Except in the case of a purchasemoney security interest which has seniority under certain conditions, ${ }^{280}$ it allocates priority to the holder of the interest first perfected when one competing party has perfected by possession and the other by filing, ${ }^{280}$ but to the first to file regardless of which security interest attached first, and whether it attached before or after filing, if both perfect by filing..$^{287}$

Momentarily passing 9-312, however, other sections of the Code suggest that a holder of field-warehouse receipts may be able to defeat claimants having perfected security interests in the same goods. Section 9-309 states explicitly that a holder "by due negotiation" of a negotiable document prevails over any security interest, whether recorded or not. ${ }^{288}$ The bank receiving negotiable

280. See note 139 supra and accompanying text.

281. See Coogan, Article 9 of the Uniform Commercial Code: Prioritics Aman! Secured Creditors and the "Floating Lien," 72 HARv. L. REv. 838, 855-56 (1958).

282. The security interest of the non-field-warehouse lender in the goods to be fieldwarehoused as substitute collateral could have already been perfected by filing beforc the field-warehouse lender's interest would perfect by possession. See notes 285-87 infra and accompanying text.

In the following discussion on perfection of a security interest, the Comment will assume, unless otherwise stated, that the interest has already attached. The interest cannot perfect unless it has attached pursuant to UCC $\$ 9-204$. UCC $\$ 9-303(1)$; Note, 68 YAl. L.J. 751, 751-52, 766-71 (1959).

283. UCC \$ 9-312(3). But see UCC \$ 9-309 (holder of negotiable document may prevail over all security interests); note 300 infra and accompanying text.

284. UCC $\$ 9-312(3)$ (b) ; note 287 infra and accompanying text.

285. UCC $\S \S 9-107,9-312(3)$; Coogan, supra note 281, at 861-66; Note, 68 YALE L.I. $751,761-65$ (1959).

286. UCC \& 9-312(5) (b) ; Coogan, supra note 281, at 866-68; Note, 68 Y YL.: L.J. $751,765-72$ (1959).

287. UCC \& 9-312(5) (a); Coogan, supra note 281, at 857-61; Note, 68 YAt.E L.J. 751, 751-56 (1959).

288. See Coogan, supra note 281 , at 870-72. Compare UTRA \& 9(a). 
field receipts would be a holder "by due negotiation" if it took them "in the regular course of business or financing" without notice of defects. 230 A prior perfected security interest would be such a defect, but since filing is not notice, ${ }^{290}$ the bank would probably prevail, unless failure to search the records would prevent it from qualifying as one who took "in the regular course of business or financing."291 But unless this possible advantage of negotiable documents causes a change in Code states in the field-warehouse companies' usual practice of issuing nonnegotiable receipts, the field-warehouse lender's position vis-a-vis the holder of a prior perfected security interest would be a most difficult one; article 9 evinces no intention that a pledgee of a nonnegotiable document should stand in any better position than the ordinary pledgee, who loses to the holders of prior perfected security interests. ${ }^{202}$ On the other hand, a section in article 7 may be employed by the field-warehouse lender in this situation. Section $7-503$ provides that "a document of title" confers no rights against the holder of a perfected security interest in the same goods unless the latter "delivered or entrusted them ... . to the bailor [in our case, the borrower] ... with actual or apparent authority to ship, store or sell ... or with power of disposition under this Act ...." The negative pregnant of this proposition is that the document-holder would prevail if the goods have been so "delivered or entrusted." In many cases, such entrusting would have occurred ; 293 the receipt-holder would therefore win under the terms of 7-503, unless that section is restricted to negotiable documents. No such limitation is found on its face, and one of the draftsmen's official comments implies that the section has application to nonnegotiable warehouse receipts.:-0- But the provisions of UWRA, the Uniform Sales Act, and the Uniform Bills of Lading Act which the draftsmen say section $7-503$ was designed to replace, dealt only with negotiable documents. ${ }^{295}$ Mloreover, 7-503 may be read as only limiting 7-502, which concerns the rights of persons taking by negotintion..$^{203}$ It is probable that the draftsmen remained unaware of the potential conflict between section 7-503 and article 9, and expected that contests between fieldwarehouse receipt-holders and other secured lenders would be governed en-

289. UCC \& 7-501 \& comment. "When a document running to the order of a named person is delivered to him the effect is the same as if the document had been negutiated." UCC § 7-501(2) (b).

290. UCC \& 9-309.

291. See notes $298-99$ infra and accompanying text.

292. See Gilmore, supra note 254, at 41 ; Birnbaum, supra note 265, at 369 \& n.96.

293. Section 7-503(1) (a) includes a direct reference to 2-403 where entrusting is broadly defined to include "any delivery and any acquiescence in retention of possession regardless of any condition expressed between the parties ...." UCC $\$ 2-403(3)$ \& comment 2; see N.Y. Study of ArTic.e 7, at 1844-47.

294. UCC \& 7-503, comment 2.

295. UCC $\$ 7-503$, comment; UWRA $\$ 41$; UNiforar Sales ACt $\$ 33$; ['sifuiss Bulls of Lading Act $\S 32$.

296. See Staff of Tex. Legislative Council, Analyses of Article 7 of the Uniform Coummercial Code, Dec. 1952, pp. 108-09; N.Y. Study of Articze 7, at 184. 
tirely by the priority rules of section $9-312 .{ }^{207}$ Originally this meant that the first to file would win, and in the subsequent decision to delete mandatory filing for field-warehouse lenders no indication appears that priority considerations played any part. The draftsmen's probable intention, that the field-warehouse lender should lose to the holder of a previously perfected interest, can be effected by reading into section 7-503 an implicit assumption that the document-holder can win only if he received the receipt "in the regular course of business or financing." 298 A bank in Code states, "in the regular course of financing," should not take field-warehouse receipts for goods stubject to any prior security interest which could be readily ascertained by checking the files. ${ }^{299}$ On the other hand, if such a check shows no other financer yet in the picture, the receipt-holder could plausibly argue that the Code should not exempt a purchase-money lender from having to ascertain, before extending credit, whether the borrower is using a field warehouse. ${ }^{300}$

Article 9's main impact on secured trade credit will be to encourage a prudent manufacturer using plan one to record and thus perfect his interest before shipping the goods. For if he is content to wait to perfect his interest by constructive possession upon deposit of the shipment in the field warehouse, he may find his interest superseded before the field warehouseman ever gets the goods. Even if the buyer has no other recorded financer at the time of shipment, the seller's perfected security interest could be defeated by creditors attaching the goods before they reach the field warehouse, ${ }^{302}$ or by a lencler who perfects a security interest in buyer's after-acquired property by filing while the goods are en route. ${ }^{303}$ But if the shipper has recorded his financing arrangement, his security interest perfects before an attempted attachment and before that of after-filing lenders. ${ }^{304}$ Nor can any other creditor obtain a purchase money security interest in the same goods, since the manufacturer is himself financing the dealer's purchase. ${ }^{305}$ As an alternative to recording, the

297. See sources cited note 292 supra; Coogan, supra note 281, at 870-71 (all implying that perfection and priorities of field-warehouse lenders will be governed exclusively by rules of article 9).

298. See UCC \& 7-503, comment 1.

299. Compare Birnbaum, stupra note 265, at 369 n.96; 9C Unirokm Laws ANN. 277 (1957) (§ 7.iv).

300. The field warehouse lender could argue that the presence of a warchouse on the debtor's premises, which could be readily perceived by inspection, would give the second prospective lender actual or constructive notice of a prior financing arrangement. Thus the second lender would have to notify the first in order to obtain a valid purchase money security interest. See UCC \& 9-312(3). The argument is based on the premise that any lender advancing money against inventory would see if it exists and is in the possession of the debtor.

301. UCC § 9-304(3).

302. UCC $\$ 9-301(1)(\mathrm{b})$.

303. UCC $\S 9-312(5)(\mathrm{b})$.

304. UCC $\$ \$ 9-30+(3), 9-303(1)$ (security interest perfects "when it has attached and when all the applicable steps required for perfection have been taken").

305. UCC \& 9-107. 
manufacturer can by virtue of section 9-304(5) retain a senior security interest throughout if he ships under a negotiable bill of lading and the buyer fieldwarehouses the goods within twenty-one days. ${ }^{300}$ The manufacturer's burden is greater if his dealer has already entered into other recorded financing arrangements. The manufacturer will then prevail over the other lender only by obtaining a perfected purchase-money security interest in the goods he ships. $^{30 \pi}$ To do this, before shipping he must both notify the other lender and comply with the other statutory requirements for perfection, $30 \mathrm{~s}$ which may be done either by filing ${ }^{309}$ or by the above-mentioned section 9-304(5) procedure. By no means, however, can the manufacturer avoid the risk that the dealer may, in breach of this agreement to field-warehouse the goods, sell them directly to a "buyer in the ordinary course of business." Sections 9-307 and $2-403$ make it clear, as earlier law did not, ${ }^{310}$ that stich a buyer takes free of the manufacturer's interest. ${ }^{311}$

Under secured-trade-credit plan two, the manufacturer would avoid all problems of competing security interests. For the manufacturer's interest throughout is one of ownership rather than security, and therefore not subject to the priority rules of article 9.312 Plan two can give rise to no security interest because the shipper retains all title and interest in the goods both en route to and during field warehousing. Even though the Code disregards the inci. dence of title as such, ${ }^{313}$ the shipper cannot be said to retain a residual securit! interest as a secured seller does, because he has never parted with any interest at all. In effect, the procedure is the same as if he shipped the goods to a terminal warehouse next door to the dealer and the latter, when he wantel the goods, went to the warehouse and paid for what he received. Moreover. the seller's interest is excluded from the Code definition of "security interest" because the dealer, having incurred no obligation to the manufacturer, has nothing to give security for. ${ }^{314}$ Nor is plan two a consignment sale under section $2-326$, because the goods have not been delivered to the dealer, but rather to the manufacturer's agent, the field warehouseman. Having no se-

306. UCC \$ 9-30t(5) (also allows such periection if the goods are released from a bailee directly to the debtor for specified purposes). The security interest would remain continuously perfected if the goods were deposited in the warehouse within 21 days. UCC $\$ 9-303(2)$. For priority purposes an interest is considered perfected in the manner-either filing or otherwise-in which it was first perfected UCC \& 9-312(6).

307. UCC \$\$ 9-107, 9-312(3).

308. UCC $\$ 9-312(3)$.

309. UCC \& 9-304(3).

310. See notes $190-96,245-46,250-52$ supra and accompanying text.

311. Section 9-307 covers goods subject to a perfected security interest; $\$ 2-403$, any items entrusted to a dealer in such goods.

312. See Coogan, supra note 281, at 868.

313. UCC \$ 9-202 \& comment.

314. See UCC $\$ 1-201(37)$. The Lawrence Warehouse $C_{0}$. is now in the process of revising their Secured Distribution Agreement-Plan 2 to ensure that it is not considered a security interest under the Code. 
curity interest, the manufacturer has no reason to file a financing statement covering the goods shipped to the field warehouse. But, if he plans to release merchandise from the warehouse to the dealer on credit, he will probably wish to perfect a security interest in these released goods. He automatically obtains a security interest for twenty-one days under section 9-304(5). To retain a security interest beyond that time, he must file a financing plan. ${ }^{316}$ In filing, he should specify that he intends to finance only those items released from the field warehouse; otherwise, a court may consider the entire arrangement a sale with a retained security interest. In that case, the arrangement would be equated with secured-trade-credit plan one, where the goods are sold but pledged back as security for the purchase price. The dealer would be able to object if the shipper tried to sell the goods elsewhere or at a higher price. Another possible hitch in plan two develops when the dealer must physically take the goods from the carrier and bring them to the warehouse.310 While his creditors would not be able to attach the items in his hands, since he has no interest in them, section 2-403 enables him to sell them free of the shipper's interest to a "buyer in the ordinary course of business."

The only field warehousing case decided under the Code which research reveals concerned a secured-trade-credit plan one arrangement. In Lazurence Warehouse Co. v. Fidelity Trust Co. ${ }^{318}$ Re-Ly-On Mattress Co. had borrowed money from Fidelity Trust Co., which filed a financing statement covering all Re-Ly-On's after-acquired goods, but no security interest ever attached because the bank did not enter into a written security agreement as required by the Code. ${ }^{319}$ Apparently the bank felt adequately protected by making advances only against Lawrence receipts covering various items deposited by Re-Lyr-On. Subsequently a cotton supplier, MacKay, made a secured-tradecredit plan one agreement with Re-Ly-On, under which MacKay shipped raw cotton to be deposited in the same Lawrence warehouse and receipted to MacKay. But MacKay failed to file the finançing statement then required by the Pennsylvania version of the Code to perfect a security interest in fieldwarehoused goods. Upon Re-Ly-On's being put into receivership for liquidation, both Fidelity and MacKay claimed certain raw cotton that had been shipped by MacKay and was still in the field warehouse, most of it receipted to MacKay. ${ }^{320}$ Lawrence interpleaded both parties and the receiver, but the

315. UCC $\$ 9-302$. If he filed within 21 days after releasing the goods, his interest would remain continuously perfected. UCC \& 9-303(2).

316. The warehouse manager could transport the goods from the carrier to the warehouse himself, thus not allowing the dealer to gain possession. But the goods are usually shipped by truck and then transported from the carrier to the warehouse by the dealer's employees, as the warehouse company does not want to assume the responsibility for them until they are deposited.

317. UCC $\S 2-403$. The section's broad definition of "entrusting" seems to bring within its coverage delivery to an "agent" for purposes of storage.

318. Civil No. 15219, W.D. Pa; June 7, 1959.

319. UCC §§ 9-203, 9-204.

320. It appears that the bank was only lending against ficld warehouse receipts issued to it, and did not make specific advances against the cotton shipped by McKay. Sec 
latter despite an apparently strong case, abandoned all claims. ${ }^{321}$ The court, faced with this comedy of errors, ${ }^{322}$ decided that MacKay, who had an unperfected security interest, defeated Fidelity, who had no security interest at all. Under the Code as amended, the shipper would have prevailed more readily, since his security interest would have become perfected without filing upon deposit of the cotton in the field warehouse. ${ }^{323}$ But had the bank made a written security agreement, the shipper's interest would obtain priority only if before shipping he had perfected a purchase-money security interest, which would have entailed notice to the bank. . $^{324}$

Fidelity may point the way to a possible solution of some of the problems caused by the Code's floating lien. Critics have maintained that the ease with which a borrower can tie up all his present and after-acquired inventory under the Code will make it difficult for him to obtain any additional credit, either secured or unsecured. ${ }^{325}$ The Code attempts to answer this problem by providing that a floating lien on after-acquired inventory will be junior to a perfected purchase-money security interest, ${ }^{3013}$ while some commentators have recommended lender self-restraint in demanding collateral, so that security interest would be sought only in specific inventory: ${ }^{32 \pi}$ But neither of these solutions provides a manner in which those goods in the debtor's possession which are subject to a floating lien are to be distinguished from those subject to the interest of a purchase-money man. Field warehousing provides a method. In the Fidelity fact situation, for example, the bank's security interest, had it been filed, would have been senior to all but purchase-money security interests, such as MacKay's. Assuming that both had perfected by filing, the warehouseman would be responsible for separately policing each category of receipted inventory. In this manner, each creditor, as well as possible future lenders, would be fully advised of the collateral available to secure his debt through field-warehouse receipts and records. In the event of litigation, the extent of conflicting claims could be readily ascertained. The use of field warchousing

Civil No. 15219, at 3. There were, in fact, seven different parties advancing credit to Re-Ly-On who also held field warehouse receipts.

321. Id. at 2.

Under Pennsylvania law the receiver apparently could have attacked and defeated both Fidelity's and MícKay's interests because they were unperiected. See PA. Stat. As:s. tit. 39, § 71 (1954); PA. Star. Axw. tit. 12A, $\$ 9-301$ (1954); Sholes v. Western Asphait Block \& Title Co., 183 Pa. 528, 38 Atl. 1029 (1898) (receiver defeated claim of pledgee where the pledged goods were not segregated).

322. See Lawrence Warehouse Co. v. Fidelity Trust Co., Civil No. 15219, IV.D. $\mathrm{Pa}$, June 7, 1959, p. 6.

323. UCC \& 9-304(3).

324. UCC §§ 9-107, 9-312(3).

325. See, e.g., 2 New York Hearirgs 1034-35, 1098, 1243-45, 1301, 1462 ; Coogan, supro note 281 , at $873-80$.

326. UCC $\S \S 9-107,9-312(3)$; Coogan, supra note 281, at 861-66; Note, 68 YALE L.J. $751,761-65$ (1959).

327. See Coogan, supro note 281, at 873-75; Silberfeld, The Year's Legal Dezelopments in Connmercial Financing, 76 BAxking L.J. 1, 2-3 (1959). 
by two or more lenders, evidenced by Fidelity may, therefore, form a pattern for future practice.

\section{A Word in Conclusion}

Field warehousing developed in response to the secured credit market's need for a device permitting borrowers to pledge inventories on their premises by giving lenders valid liens in the goods. Now that alternative lien-validating methods are available under the Commercial Code and other statutes, the field warehouseman's most distinctive service to the lender is his double-barreled guaranty of the collateral, both as policeman and as assumer of risks. And since warehousing law-under both UWRA and article 7-provides a set of workable legal principles, no need exists for the lender seeking an independent watchman of his interest to resort to direct contractual arrangements or special legislative action. ${ }^{328}$ Through the issuance of warehouse receipts, for which the lender can, if necessary, find a ready commercial market, the field warehouse company obligates itself to deliver the collateral to the receipt-holding creditor. Their potential liability on the receipts provides incentive for them to care for the goods. Finally, the fiexibility allowed by field-warehousing methods has enabled the industry to cater to the business community's increasing demand for inventory financing, through conventional field-warehousing methods or secured trade credit. In sum, rumors of the field warehouseman's death, like those of Mark Twain's, have been greatly exaggerated.

328. Cf. Gilmore, The Secured Transactions Article of the Commercial Code, 16 Law \& Contemp. Prob. 27, 31 \& n.19 (1951). 